Article

\title{
Resource Dynamism of the Rwandan Economy: An Emergy Approach
}

\author{
Evariste Rutebuka $\left.{ }^{1,2,3} \mathbb{( 1}^{(}\right)$, Lixiao Zhang ${ }^{1, *}$, Ernest Frimpong Asamoah ${ }^{4}\left(\mathbb{D}\right.$, , Mingyue Pang $^{1}$ \\ and Emmanuel Rukundo ${ }^{1}$ \\ 1 State Key Joint Laboratory of Environmental Simulation and Pollution Control, School of Environment, \\ Beijing Normal University, Beijing 100875, China; ruteva07@gmail.com (Ev.R.); \\ pangmingyue@mail.bnu.edu.cn (M.P.); rukundo1@gmail.com (Em.R.) \\ 2 Department of Environment Management, Institute of Life and Earth Science, \\ Pan-African University (PAULESI), Ibadan 200284, Nigeria \\ 3 Department of Agricultural and Environmental Engineering, Faculty of Technology, Ibadan University, \\ Ibadan 200184, Nigeria \\ 4 Department of Environment Sciences, Faculty of Science and Engineering, Macquarie University, \\ North Ryde 2109, Sydney, Australia; asamoahfr_imp25@hotmail.com \\ * Correspondence: zhanglixiao@bnu.edu.cn; Tel.: +86-135-8190-3736
}

Received: 19 March 2018; Accepted: 25 May 2018; Published: 29 May 2018

\begin{abstract}
Africa is experiencing unprecedented economic growth that requires planners to understand the interactions between the social, economic, and ecological systems to ensure its sustainable development. The present paper uses the emergy method to analyse the Rwandan economy from 1975 to 2016. Emergy-based sustainability indicators were used to analyse and compare two distinct periods of economic growth: the pre- and post-Tutsi genocide periods. The results revealed that, by 2016, the total emergy use had increased by approximately $74 \%$ of the emergy recorded in 1975. The increase in total emergy use was associated with an increase in imports with contributions from 6.5 to $46.2 \%$ and the renewable resource contribution decrease from 93.5 to $53.8 \%$. The emergy analysis, which covered 41 years, categorises Rwanda as a non-renewable resource-poor country. The total emergy use of the pre-genocide period was significantly lower than the post-genocide period. Based on the 2016 emergy self-support of $54 \%$ and the emergy sustainability index of 2.52, Rwanda has the highest import dependence compared to other developing countries listed in this paper and tends toward a developed country like Canada, Portugal, and so on. An imperative decision needs to be made in terms of the management of the economic system of Rwanda, as imports are becoming the highest impetus of the Rwandan economy but are also the top major cause of a long-run sustainability downfall. Thus, the present study recommends a scrutinised selection system of imports by increasing raw materials, particularly non-renewable resources, and by subsequently increasing the internal transformation to be exported. This recommendation is also applicable to other developing countries with similar non-renewable resource statuses.
\end{abstract}

Keywords: emergy; economy; resources; Rwanda; sustainability; developing countries

\section{Introduction}

A country's economic developments rest on its environment inputs. Mostly, there are negative externalities associated with these developments [1-3]. These externalities become worse when the development rate increases and the ecological and environmental aspects are not carefully considered in economic decisions. The effects of these externalities aggravate more when mitigation and management options are not financially and politically viable [4]. According to the International Monetary 
Fund [5], Africa is second to Asia as the continent that is facing such an economic development and population growth. However, these externalities may restore the degraded ecosystems [6]. Apart from the high economic desire, the high population growth and the high population density are vital drivers of environmental and ecological impairments [7-9], which reflect the population demography in Africa. For instance, the population in 1980 was estimated at 478 million, but it has since tripled to 1.2 billion and is projected to be 1.5 billion by 2025 and 2.4 billion by 2050 [10]. Both the economy and population growth of Africa needs a substantial evaluation to properly document environmental sustainability and inform policymakers on that matter. Scaling to the country level can elucidate how African economies and the environment work and contribute to sustainable development. Considering the economy and population growth during the past three decades, the country of Rwanda was chosen as the case study.

Traditionally, both ecology and economic disciplines address complex systems, yet they work in isolation from each other [11]. Traditional economics focus on the efficient allocation of resources (for example, natural resources), but mostly ignores the aspects of environmental externalities. This isolation has resulted in policies that pay limited attention to the environment and the whole ecological system [11]. A standard economic theory and monetary valuation approach has been used to bridge ecological and economic complexities, but they underestimate the importance of natural resources and fail to value the work of nature and to set the metric unit [12,13]. The emergy approach, which considers the geologic processes, atmospheric systems, ecosystems, and societies as interconnected systems, normalises all products and services to a unit of measure that represents the quantity and quality of work being created and maintained by the system, namely solar emjoules (sej) [14].

Previously, emergy analysis has targeted and extensively evaluated various macro and microeconomics of the environmental interfaces at the national and provincial scales in Switzerland, France, Sweden, Japanese, Norway, Canada, Brazil, Turkey, Italy, US, China, and so forth [15]. The African system has been neglected and no African country has tempted to evaluate its current or historical economic development situation with the emergy method. Thus, the emergy-based application in Rwanda will bridge the research gaps on the Africa continent $[16,17]$ and guide policies to enhance the environmental management and sustainable development.

Emergy can inform various policies and decision-making at the macro and micro levels, and in simple to complex systems [11,15,18-21]. The present study focuses on the Rwandan economy because of its soaring pace of economic development. We evaluated its sustainability to inform decisions while covering the spatial distribution of the emergy application gap. Besides, emergy indicators from previous studies have assumed the difference between developing and developed countries but there is no statistic testing to prove this hypothesis [22-25]; therefore, this hypothesis was tested.

\section{Materials and Methods}

\subsection{Study Area}

Rwanda, officially the Republic of Rwanda, is a sovereign state in East Africa. It shares borders with Uganda, Tanzania, Burundi, and the Democratic Republic of the Congo (Figure 1) [26]. Rwanda is also known for its tragic Tutsi genocide story of 1994 and its economic rebirth after tragic events, an exceptional post-conflict success story [27]. Rwanda is $26,338 \mathrm{~km}^{2}$, landlocked, and the highest densely populated country in Africa, when Islands are excluded, with 208 persons $/ \mathrm{km}^{2}$ in 1980, 471 persons $/ \mathrm{km}^{2}$ in 2015, and a projected 620 persons $/ \mathrm{km}^{2}$ in 2032, and with a population growth rate by which the 2016 population was almost thrice the value of that in 1975 [10,28]. The Rwandan government initiated the Vision 2020 development program in 2000 that aims to increase the annual per capita income from 220 USD in 2000 to 900 USD in 2020 [29,30]. Now Rwanda is recognised as one of the ten fastest growing economies in the world and has been ranked as the second most reformed economy in the world over the last five years [31]. Astonishingly, Rwanda's development is contrary to other African countries with similar economic development rates, as much of their development is attributed to the booming commodity prices for mineral, oil, and other natural resources [31]. 
This implies that Rwanda has little to do with the commodity (that is, minerals, oil, and so forth) windfalls since it is a natural-resource-poor country. Excluding the highest populated by density African islands, Rwanda is currently the most densely populated country in Africa [7-9].

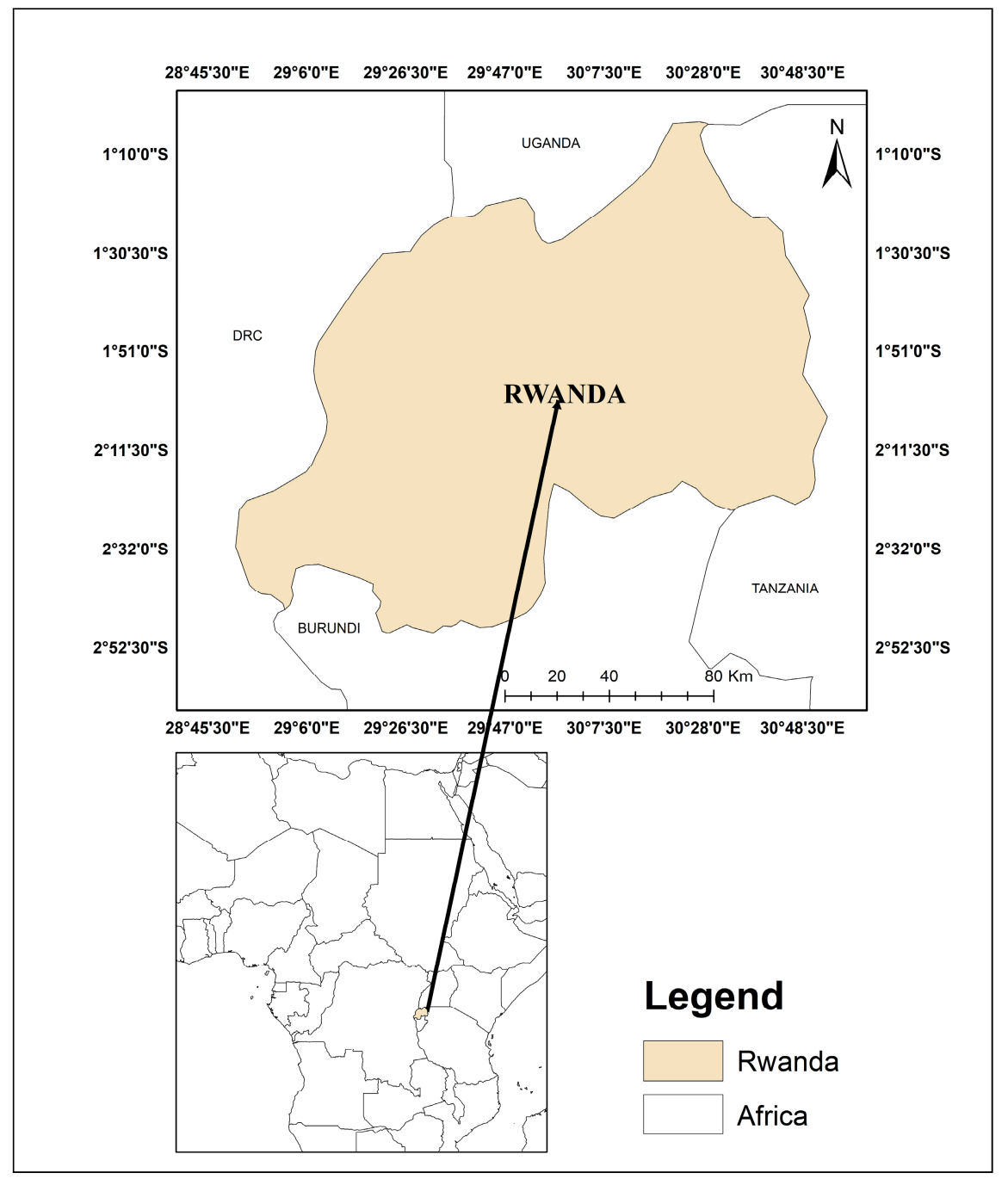

Figure 1. The location of Rwanda.

From 1961 to 1990, Rwanda had an administered economy and has imposed severe restrictions on trade and foreign exchange transactions as well as a fixed exchange rate regime. By the early 1990s, the average tariff rate was $34.8 \%$, with five different tariffs ranging from 0 to $60 \%$. Every import and every import was subject to a quota, and all import operations were subject to a license authorising external currency disbursement [32]. Exporters had to repatriate currency generated by the sale of exports as a legal requirement and export licenses were authorised only by the National Bank of Rwanda (BNR), the central bank of Rwanda. More importantly, all export earnings were transferred to and managed by the BNR. Likewise, the BNR had to give prior approval for certain invisible transactions, including medical care, tourist trips, and studies abroad, with purchases of currencies from the BNR to finance these invisible transactions subject to ceilings [32,33].

Post-genocide in 1995, some economic reforms were implemented in Rwanda. Rwanda embraced a market economy characterised by both a continuation of trade reforms and a liberalisation of the monetary and financial regimes. Tariffs were reduced considerably with the average rate decreasing to $18 \%$, and there remained four tariff bands with a maximum of up to $30 \%$ by 2003 , which was 
a significant reform when compared with the tariffs before 1994. The liberalisation of the monetary and financial sector led to the adoption of new currency exchange regulations, the creation of new private commercial banks, and the privatisation of banks that had been state-owned [32,34].

Tea, minerals, and coffee dominated Rwandan exports until 2008 when they declined from $94.4 \%$ in 2001 to $79.12 \%$ in 2008. Rwanda's non-traditional exports include alcoholic beverages, vegetables, and non-alcoholic beverages respectively representing $5.4 \%, 3.7 \%$, and $3.7 \%$ of the exports in 2008, from near zero in 2001. Its export performance was weak with an annual export of 18 USD per capita, compared to the average 145 USD for sub-Saharan Africa in 2008. Rwandan exports, including tourism, have increased significantly over the past decade, rising to 454 million USD in 2010, but its imports have been growing more rapidly than exports, from 282 million USD in 2003 to 1.3 billion USD in 2010. The GDP per capita has increased from less than 200 USD in 1994 following the Genocide against the Tutsis to 540 USD in 2010, while it moved from 132 USD to 249 USD from 1975 to 1990, respectively [32].

\subsection{Emergy Analysis}

The emergy method, first presented by H. T. Odum, is based on the principles of thermodynamics and general systems thinking. By definition, emergy is the available energy of one kind that was used up in transformations, directly and indirectly, to make a product or service [35,36]. Emergy synthesis is performed by converting the energy, mass, or money value of the different inputs (natural and economic products and services) required to make a good into the common unit of solar emjoules [35], considering solar energy to be the most essential energy involved in all biogeochemical processes of the earth [37]. The amount of emergy required to produce a unit of energy, mass, or money is referred to as the Unit Emergy Value (UEV) and is expressed as sej/J, sej/g, and sej/\$. The UEV is a measure of the process efficiency, that is, the lower the UEV, the more efficient the conversion [38].

To conduct this study, data were collected from the National Bank Rwanda's database on export and import data from 1975 to 2016. The external commerce of exports, imports, and other economic statistics are recorded in the quarterly bulletin of the National Bank of Rwanda. Additional data were collected from other Rwandan governmental institutions like the National Institute of Statistics of Rwanda (NISR), the Ministry of Commerce and Trade, the Ministry of Agriculture and Animal Husbandry, and the Ministry of Natural Resources. The world development indicators (WDI), food and agriculture FAOSTAT (http:/ / faostat3.fao.org), were consulted for data on livestock and crop productions.

To test the differences of emergy indicators between developed and developing countries, previous emergy indicators were sampled from previous national emergy accounting studies. The emergy system diagram developed for Rwanda has followed the typical diagram of a nation [35]. Figure 2 depicts the primary emergy flows of the Rwandan economy. These flows include free renewable environmental resources, local non-renewable resources, imported commodities, purchased services, and exchanges of money and information.

The emergy baseline is critical to ensure the accuracy of our calculations, but it has been changed from $9.44 \times 10^{24} \mathrm{sej} /$ year [35] to $15.83 \times 10^{24} \mathrm{sej} /$ year after considering the change of energy absorption in the earth movement [39]. However, further recalculation has kept taking place where the most recently updated is $12.00 \times 10^{24} \mathrm{sej} /$ year $[40,41]$. Therefore, with the latest baseline, all the UEVs before the year 2000 were multiplied by 1.27, and those after 2000 to the most recent baseline were multiplied by 0.75 . 


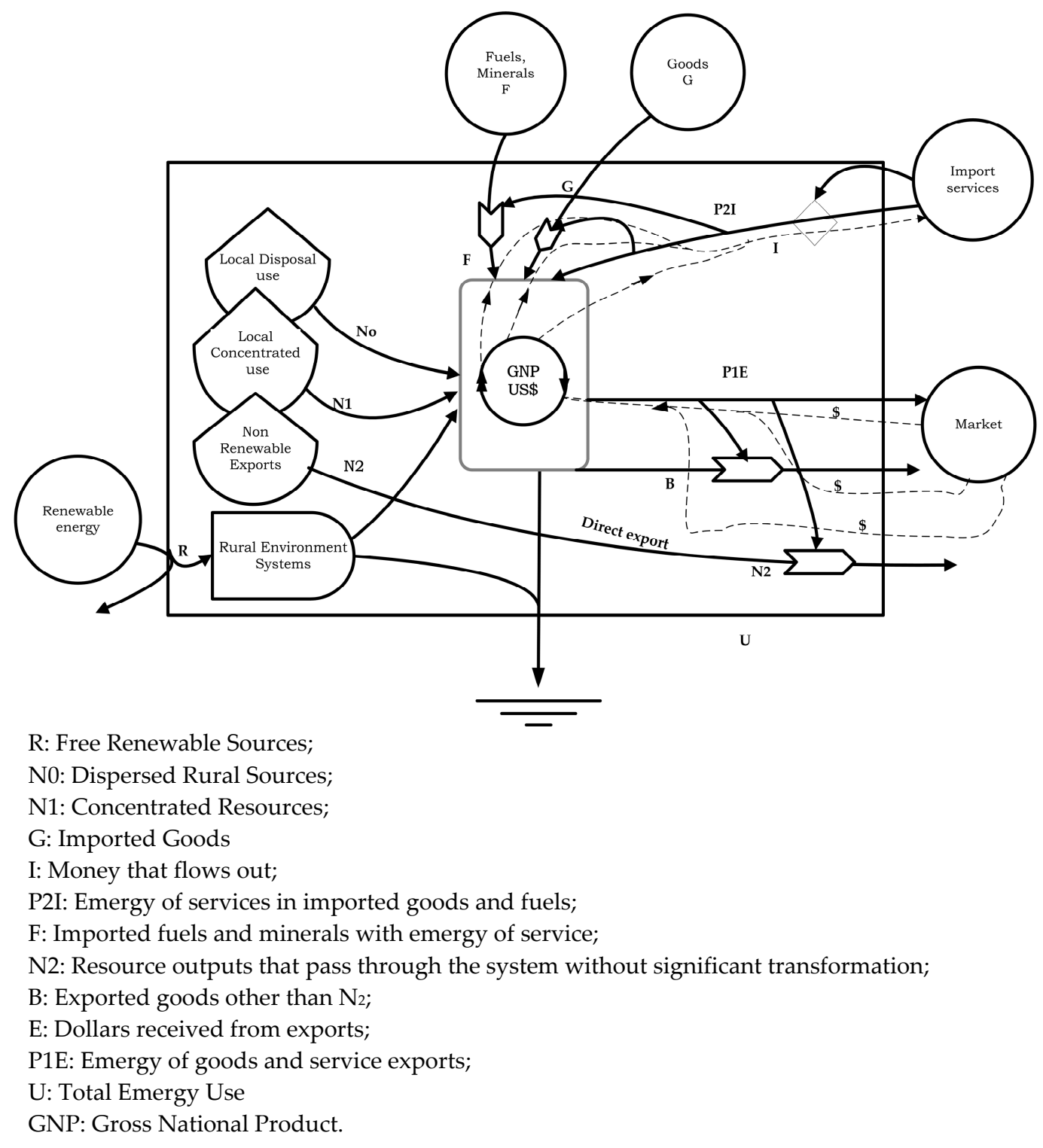

Figure 2. The aggregated resource flows of the Rwandan economy.

\section{Results and Discussions}

\subsection{Resource Accounting}

Emergy analysis divides renewable resources into two components: free renewable resources from the environment and indigenous renewable resources. The free renewable resources from the environment are absent resources on the market and difficult to be assessed by money-based evaluation. It includes the earth cycle, sunlight, rain, and the wind in which rain was its major composite by about $90 \%$ of the $3.69 \times 10^{22}$ sej of the renewable resources since 1975 (Table A1 in Appendix A). The indigenous renewable resources are hydroelectricity, crop production, livestock, and forest extraction. These resources are usually omitted from the computation of the total emergy use (U) to avoid double accounting into the emergy analysis [42-45]. Among the total indigenous renewable resources, forest extraction was the major contributor at $38 \%$ in 1975 , but it dropped to $30 \%$ in 2016. At the same time, crop production dropped to $22 \%$ in 2016 from $32 \%$ in 1975 . The hydroelectricity increased from 1 to $4 \%$, while livestock increased from $29 \%$ in 1975 to $44 \%$ in 2016 . 
The total emergy use (U) increased by $74 \%$ from $3.63 \times 10^{22}$ sej in 1975 to $6.31 \times 10^{22}$ sej in 2016 (Table A2). The emergy from free renewable resources $(\mathrm{R})$ contribution to the $\mathrm{U}$ declined from $93.48 \%$ in 1975 to $53.76 \%$ in 2016 . The import emergy contribution to the U increased from $6.51 \%$ in 1975 to $46.17 \%$ in 2016. The free renewable resources were the major contributors to the total emergy use and the major impetus of the Rwandan economy over a period of 41 years, but it was stagnantly stable over 41 years, whereas the import resources increased by 12 times from 1975 to 2016 and is inclined to replace $\mathrm{R}$ as the major impetus of the Rwandan economy. This substantial increase in imports has made the country more dependent on imports than before.

The indigenous non-renewable resources $(\mathrm{N})$ component is not a significant impetus of the Rwandan economy as it almost constantly contributed $0.01 \%$ to the total emergy use since 1975 . The non-renewable resources decreased from $1.31 \times 10^{19}$ sej in 1975 to $3.86 \times 10^{18}$ sej in 1995 and then increased to $5.39 \times 10^{19} \mathrm{sej}$ in 2016 . The indigenous non-renewable resources are further categorised into dispersed rural resources $\left(\mathrm{N}_{0}\right)$, concentrated resources $\left(\mathrm{N}_{1}\right)$, and non-renewable exported resources without significant transformation $\left(\mathrm{N}_{2}\right)$. $\mathrm{N}_{0}$ designates resources whose stocks are being used faster than they are re-grown, such as topsoil loss. Additionally, $\mathrm{N}_{1}$ and $\mathrm{N}_{2}$ represent the reserves of minerals that are formed and renewed over more extended geologic periods. Topsoil, the sole constituent of $\mathrm{N}_{0}$, constituted $24.46 \%$ of the indigenous non-renewable resources in 1975 but decreased to $5.95 \%$ in 2016 . Mineral extraction accounted for $75.54 \%$ in 1975 and $13.70 \%$ in 2016, while methane gas contributed to 80.35\% in 2016 from null in 1975 (Table A1).

On international exchange, the total imports increased from $2.36 \times 10^{21}$ sej to $2.91 \times 10^{22}$ sej, while the exports increased from $7.23 \times 10^{20}$ sej to $8.61 \times 10^{21}$ sej (12 times) from 1975 to 2016. Import and export imbalances occurred throughout the 41-year study period (Table A2). Among imports, fertiliser underwent the greatest growth where it increased by 117 times from 1975 to 2016. This was followed by transport machinery and tools (25 times), construction materials (13 times), food products (11 times), miscellaneous imports (8 times), and services (4 times). In 1975, the major import constituent was miscellaneous imports (27.64\%), followed by food products $(27.32 \%)$. Food product import dramatically increased from 1975 to 1985 (ten times) with a 54\% import constituent in 1985. The transport machinery and tools took over the miscellaneous imports and food products in 2005. From then on, it was a leading constituent with $44 \%$ in 2016, and the food products and miscellaneous imports dropped to 23 and $18 \%$, respectively (Table A1). The imports increased significantly from 1975 to 1981 (four times) and decreased in 1990 before turning to a reasonably steady growth from 2000. The observed increase in the total imports until 1985 is attributed to food products such as milk, milk products, birds eggs, cereal flours, and seeds as Rwanda was facing a pronounced hunger due to crop failure [46]. The noted import that increased from 2000 was machine and tool production, showing that the Rwandan modern factory industry sector was developing fast and becoming very dependent on machines, transport, and tools to fasten the small industry productions and beverages.

Among exports, the service decreased from 1975 to 1995. Since then, there was a fast growth of export services, which surpassed import services from 2000 until 2016 (Table A3). Apart from services, exports also relied on coffee, tea, and minerals. Coffee and tea have been the major exports of Rwanda. However, there was a significant drop in the coffee exports in 1995, and since then it has been almost stagnant until 2016. The export of tea and minerals are increasing. The tea export increased by 6.28 times from $3.11 \times 10^{18}$ sej in 1975 to $1.95 \times 10^{19}$ sej in 2016 (Table A1).

\subsection{Emergy-Based Indicators}

The emergy use per person (EUP) is more effective in revealing the real living standard of a nation since it accounts for not only the distinctive qualities of input joules but integrates the non-renewable resources and the renewable resources [23,43]. The EUP indicator for Rwanda dropped from $8.33 \times 10^{15}$ sej/person in 1975 to $5.30 \times 10^{15} \mathrm{sej} /$ person in 2016, which shows almost a double decrease in the living standard during the period of 41 years (Figure 3). This can be partly linked to the population 
steadily increasing from 4.36 to 11.9 million in that period [28]. This study clearly showed how the EUP is distinctly different from the GDP economic indicator as the Rwandan GDP per capita has increased almost five times from 137 to 702 USD during the same period [28]. Compared with developed countries such as Switzerland, Sweden, and others in Table 1, the EUP of Rwanda in 2016 is lower, indicating that Rwanda has a relatively lower level of technological and industrial development [47]. Moreover, in developing countries, Rwanda scores a lower EUP compared with China in 2004, as a Rwandese person in 2016 was living on a third of the wealth of a Chinese person in 2004 (Table 1) [43].

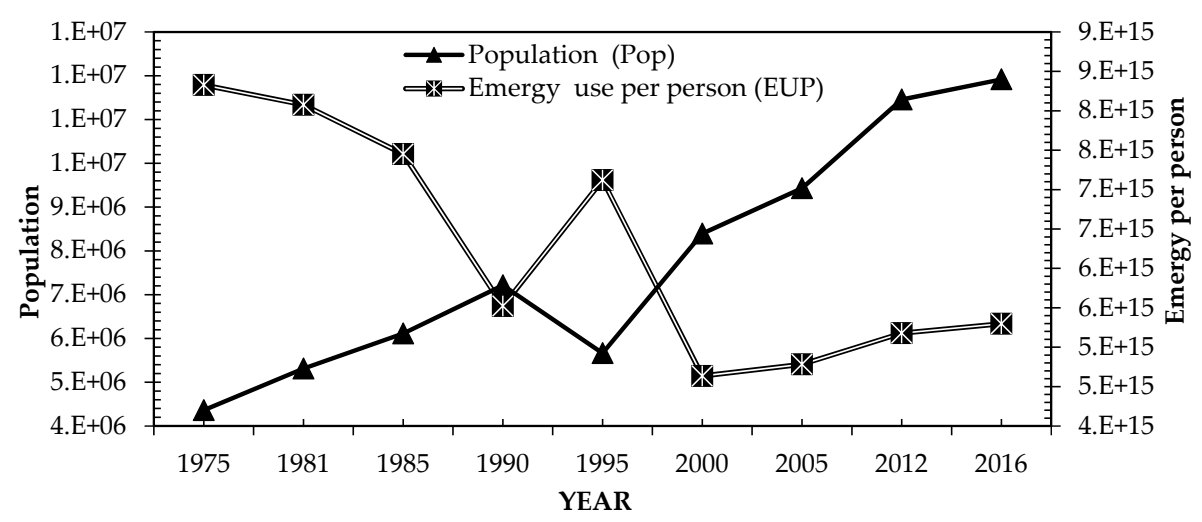

Figure 3. The emergy use per person (EUP).

The emergy/dollar ratio, or "emdollar," is the total emergy use (U) divided by GNP and is used to value the purchasing power of money [35]. Developing countries usually have a higher emergy/dollar ratio because their economy embraces a more direct use of their environmental resources without money exchange [47]. The Rwandan emdollar was $6.31 \times 10^{12} \mathrm{sej} / \$$ in 2016 , showing a decrease by $87.54 \%$ from 1975 . This decreasing trend correlates with the decreasing purchasing power of real wealth per dollar in Rwanda. Explicitly, one dollar in 1975 was able to purchase 7.32 times the real wealth of 2016. Despite the decrease in the emdollar, it was higher than almost all of its counterparts' old emdollar values in Table 1, except for Liberia and Dominica, Ecuador, Papua New Guinea, and China, which are also developing countries.

Regarding energy and resources exchange, the more trade, the more the imbalance between Rwanda and the developed countries as long as the latter has a lower emdollar $[23,47,48]$. This implies that dollar-earning from the export of raw materials in the large-scale tends to drain out the Rwandan system rather than to benefit it as the exchange of environmental commodities generally transfers much more emergy to the purchasers than what the paid money can buy from these developed countries. This describes the fact that Rwanda has been losing in most international trades. This inequity varies from country to country, but based on the world emdollar, Rwanda lost 11 times in 2000. If we were to compare the trade between China with an emdollar of $12.08 \times 10^{12} \mathrm{sej} / \$$ in 2004 and Rwanda with that of $17.30 \times 10^{12} \mathrm{sej} / \$$ in 2005 , Rwanda lost $43.6 \%$ of the purchased emergy. In 2016, the Rwandan emdollar dropped to $56.6 \%$ of that in 2005 (Figure 4), which might have reduced the unfair trade with developed countries if their emdollar dropped to a lower rate than that of Rwanda.

The indices of equity in an exchange between states or nations are determined by comparing the imported and exported emergy through the emergy exchange ratio (EER). The EER is defined as the exported emergy over the imported emergy and is expressed as $\left(\mathrm{P}_{1} \mathrm{E}+\mathrm{B}+\mathrm{N}_{2}\right) /\left(\mathrm{P}_{2} \mathrm{I}+\mathrm{G}+\mathrm{F}\right)$ [15]. The EER explains whether a state or nation is a support area for others and indicates the degree to which a system contributes to or receives from a trading partner [43]. The additional explanation of the equity is the emergy imbalance that is the difference between exported and imported emergy $\left(\mathrm{P}_{1} \mathrm{E}+\mathrm{B}+\mathrm{N}_{2}\right)-\left(\mathrm{P}_{2} \mathrm{I}+\mathrm{G}+\mathrm{F}\right)$. Based on EER, the country can either decide to use environmental commodities from domestic sources or import them from abroad $[35,47]$. As shown in Figure 5, the EER ratio is less than one from 1975 to 
2016, that is, the export minus import was negative, indicating that of Rwanda is a dependent economy. There was an apparent upward trend with the ratio increasing toward one since 1995. This upward trend shows that the Rwandan economy dependence is decreasing fast from 1995 to 2016 with a ratio moving from 0.08 to 0.30 . Despite this move, the imbalance increased from $-5.92 \times 10^{21}$ to $-2.05 \times 10^{22} \mathrm{sej} / \mathrm{yr}$ from 1995 to 2016, which means that the system is exchanging higher emergy quantity than it was before. The EER distinctively separates the pre- and post-genocide periods, since the natural resource dependence decreased after the genocide of 1994 (Figure 5).

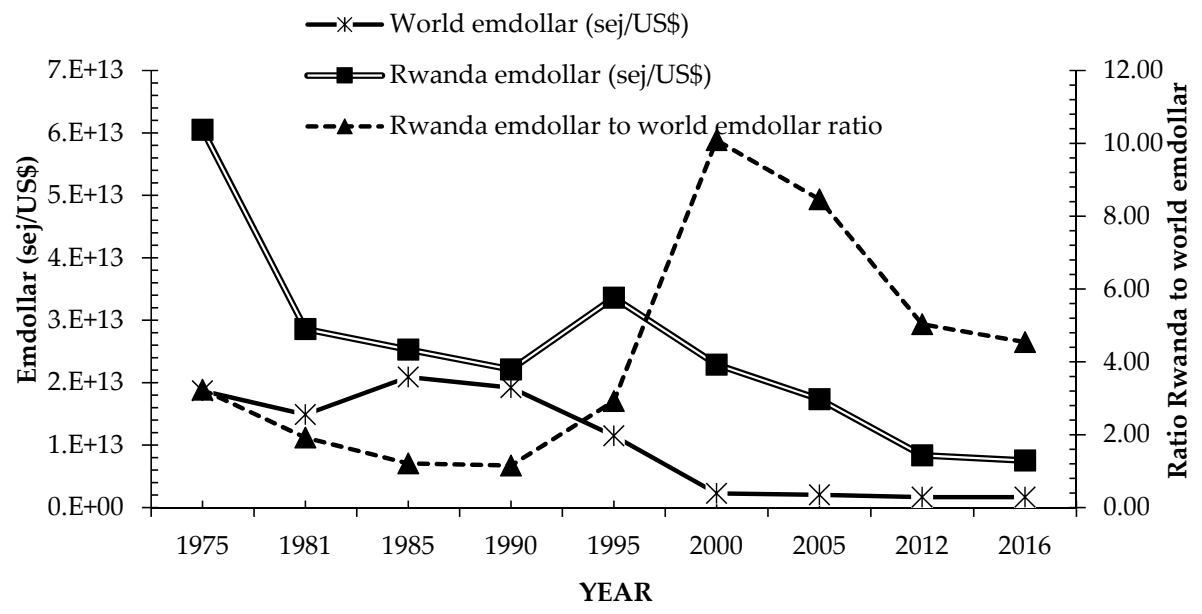

Figure 4. The Rwandan emergy dollar (emdollar).

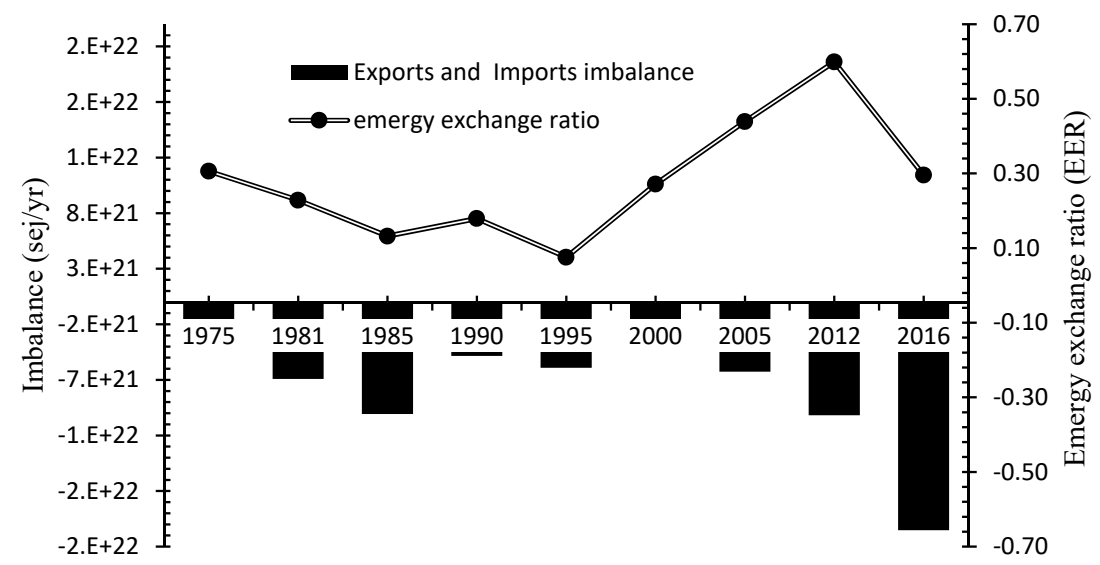

Figure 5. The imbalance between Rwanda and its foreign trading partners.

The environmental loading ratio (ELR) is the ratio of indigenous non-renewable $(\mathrm{N})$ and imported emergy to the renewable emergy (R) [18], and ELR reveals the pressure on the environment $[23,44,49]$. The ELR in Rwanda rose from 0.07 in 1975 to 0.86 in 2016 (12.3 times), as shown in Figure 6. This increase is driven by high imported emergy because $\mathrm{N}$ represented only a ratio of 0.0014 in 1975 and 0.0013 in 2016 to the imports. The recent imports increase from 2000 correlates with the foreign investment companies increased along with the foreign cash inflow increased from 145.9 million USD in 2008 to 476.3 million USD in 2015 in Rwanda [50]. The ELR values from 1975 to 2016 revealed that the Rwanda economy does not put much pressure on the local environment compared to non-environmentally-friendly countries such as China (9.29), Italy (9.47), Japan (8.34), Netherlands (15.9), Poland (19.78), and Portugal (22.6) [18,19,47]. Rwanda still has a very low ELR, and this suggests a relatively low level of technology development, which marks its relative environment impacts. 
The emergy yield ratio EYR $=(\mathrm{N}+\mathrm{R}+\mathrm{F}+\mathrm{G}+\mathrm{P} 2 \mathrm{I}) /(\mathrm{F}+\mathrm{G}+\mathrm{P} 2 \mathrm{I})$ is a measure of how much an investment pushes a process to exploit the local resources and enhances its contribution to the economy, reflecting the ability of a certain system to provide energy to the economy by magnifying its investment. The higher the EYR value, the lower the system's dependence on economic investment [18,36,51]. From 1975 to 2016, the EYR was controlled by investment (imported emergy), as non-renewable and renewable resources were almost constant throughout the study period (Table A1). It is worth noting that, when the imported emergy increased, the EYR decreased automatically, regardless of the situation (Figure 6).

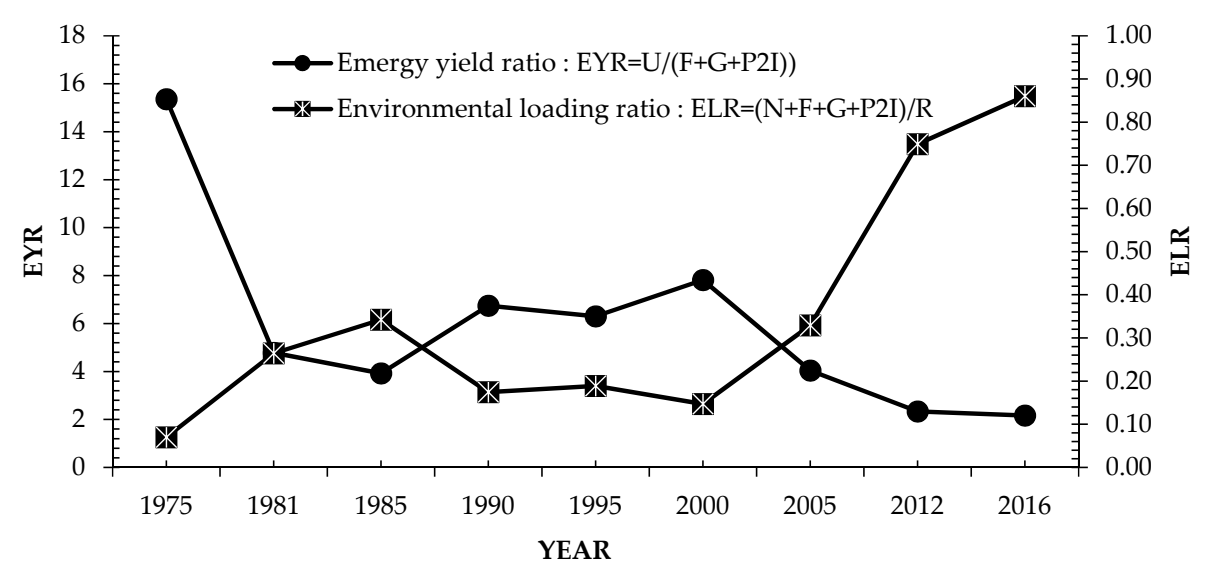

Figure 6. The variation of environmental loading ratio and emergy yield ratio.

The emergy investment ratio EIR $=(\mathrm{F}+\mathrm{G}+\mathrm{P} 2 \mathrm{I}) /(\mathrm{N}+\mathrm{R})$, the quotient of purchased emergy divided by the free emergy, can explain the feedback intensity of the economy [35]. It is an indicator of the competitiveness of a nation in attracting additional investments, and a lower ratio is more attractive for future development [52]. The higher the EIR, the more intensive the environmental use becomes and the more the money will circulate, and thus the higher the economic development level of a system will become. As shown in Figure 9, the EIR in Rwanda rose from 0.07 in 1975 to 0.86 in 2016, indicating a significant similarity with the variation of ELR. This similarity implies that the contribution of indigenous non-renewable resources $(\mathrm{N})$ into the Rwandan economy was trivial and that the Rwandan economy is enriched mainly by purchased resources. The triviality of $\mathrm{N}$ is shown again by the high similarity of the emergy self-support $(\mathrm{N}+\mathrm{R}) / \mathrm{U}$ and fraction of local renewable resources $(\mathrm{R} / \mathrm{U})$ in Table A2. The marked EIR drop in the 1990s is due to the country's insecurity, which led to the Tutsi Genocide of 1994 and an import level that was quite low. In the context of a low EIR, which is attractive for foreigners investors, the Rwandan government launched the Economic reform policy in 2000 to attract foreign investors by increasing their confidence in the country's business climate and implemented a total of 47 pro-investment policy reforms across all indicators of the Doing Business indicators in $2005[50,53]$. The aim of the reform was to turn the country into a system with high-level technology, high money circulation, and a high level of economic development. As a result of the reforms, the foreign cash inflow increased from 145.9 million USD in 2008 to 476.3 million USD in 2015, whilstthe number of registered foreign companies increased from 140 in 2009 to 209 in 2015. This reform boosted the EIR from 0.15 in 2000 to 0.86 in 2016 (Figure 9).

The emergy self-support ratio $(\mathrm{ESR})=(\mathrm{N}+\mathrm{R}) / \mathrm{U}$ measures how the environment contributes to the production of a system. The higher the ratio, the less the country depends on imported resources $[15,47]$. In 1975, the ESR was 94\%, indicating that the Rwandan economy system was very much self-supporting and that most of the resources consumed in Rwanda came from the indigenous environment. Self-support dropped to $75 \%$ in 2000. The economic reform that began in 2000 increased imports, leading to the decline of ESR $[29,30]$. The higher the ESR value, the higher the security of the national economy $[15,47]$. Compared to other countries listed in Table $1[18,19,47,54-56]$, the ESR of Rwanda in 2016 (54\%) indicates a higher insecurity economy, akin to developed countries in the 
1990s such as Portugal in 2009 (54\%) and Japan (31\%), than all other developing countries, such as Ecuador (94\%), China (81\%), and Liberia (92\%).

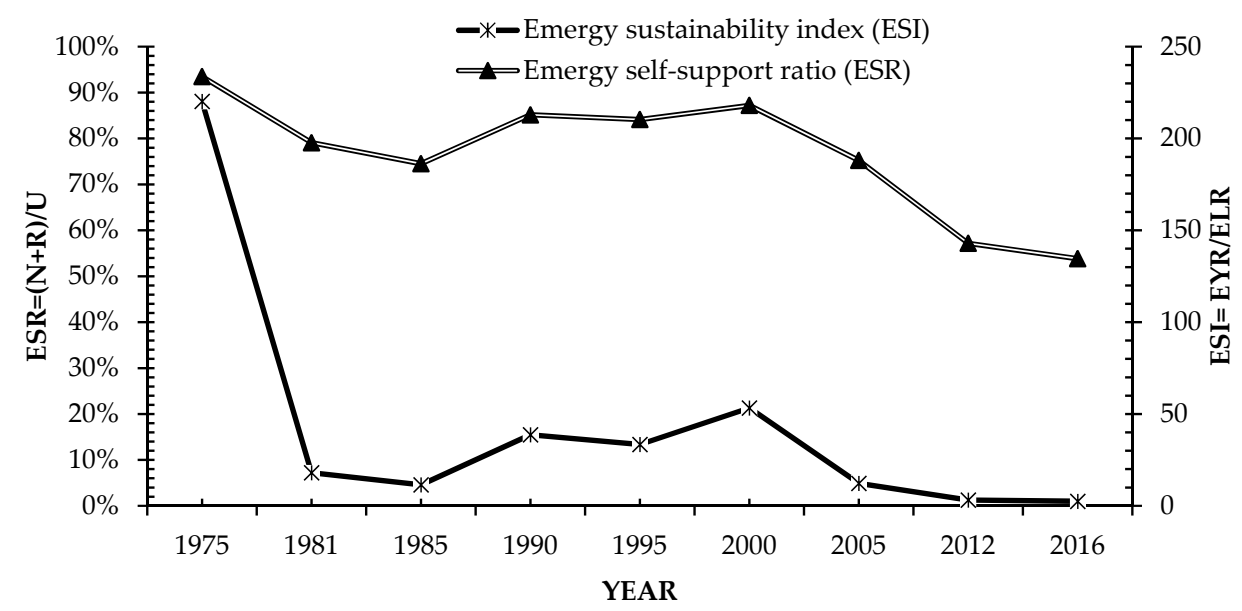

Figure 7. The variation of emergy self-support ratio and emergy Sustainability Index from 1975 to 2016.

The emergy sustainability index (ESI) $=$ EYR/ELR is an aggregate measure of yield and environmental loading and measures the production of a system relative to the environmental pressure on it $[57,58]$. The ESI was high at 220 in 1975, supported by the fact that the Rwandan economy was $94 \%$ self-dependent and had a very low loading ratio (0.07). Since 1979, Rwanda faced famines in which floods made it impossible to cultivate crops followed by a drought in 1980, which caused hunger in the following years of the 1980s. During this period of hunger, Rwanda received food products and clothing items for its people from the World Food Programme (WFP) [46]. This famine period caused a dramatic increase in food imports by six times, and the total imports increased by four times from 1975 to 1981, in which the food products were $43 \%$ of the total imports (Table A1). These heavy imports caused by the famine caused a dramatic ESI drop to 18.8 in 1981 and 11.4 in 1985. The ESI then started to fluctuate between 53 to 12 until 2005, in which the ESI was still higher than 10 (Figure 7). The Rwandan system in 2005 was classified as sustainable in the long run or as an undeveloped economy, as its ESI was more significant than $10[18,51,57,58]$. Since 2012, the ESI value has been less than 10, suggesting a relatively weak sustainability compared to those of developed countries [51] such as Portugal with 0.10 in 2009 and Canada with 1.59 in 2011 [18,19].

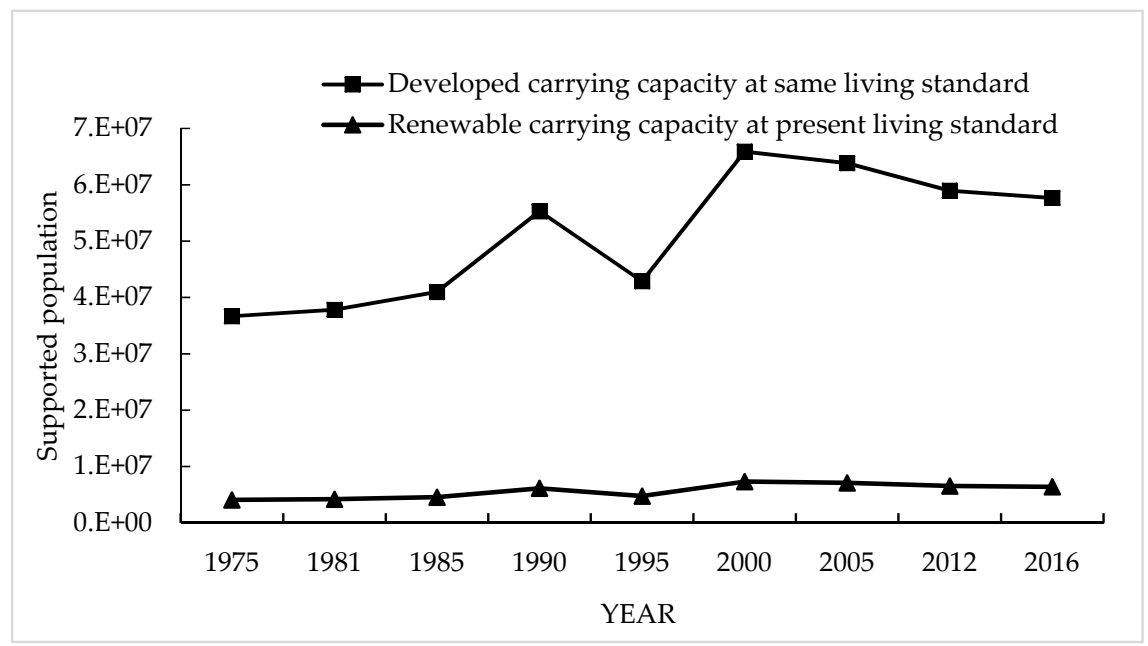

Figure 8. The trend of carrying capacity. 
Lou et al. [59] suggested that less dependency on the outside and on non-renewable resources would increase the ESI, making the country more sustainable [59]. Among these options, decreasing the dependency on outside resources is more likely to be an answer for the Rwandan ESI as long as its indigenous non-renewable resources $(\mathrm{N})$ are still negligible compared with its import resources. On the other side, $\mathrm{N}$ can contribute to the increase in $\mathrm{U}$ and then lead to the increase in EYR. Unfortunately, the ratio of $\mathrm{N}$ to $\mathrm{R}$, ranging from 0.01 to $0.07 \%$, also reveals that the $\mathrm{N}$ is negligible in the Rwandan economy. Thus, indigenous non-renewable resources cannot be thought as crucial when addressing the short running sustainable index of Rwanda, but developed countries with a good reserve of $\mathrm{N}$ can consider them in decision processes in case they need to adjust their ESI (Table A1). The reason behind this ESI similarity with the emergy system economy of developed countries is because Rwanda is a non-renewable resource-poor reserve country [31].

The carrying capacity can be determined based on the emergy requirements for a given population or the emergy intensity of a given economic development. The carrying capacity of an environment is determined by that environment's ability to supply the required emergy. A rich environment can support larger populations or more intensive economic developments [60-62]. The renewable carrying capacity at present living standards measures the number of people that could be supported by renewable sources alone, if they maintained today's living standard and is calculated as the ratio of renewable resource emergy to the total emergy use multiplied by the population $[56,63,64]$. The Rwandan renewable carrying capacity moved from $4.07 \times 10^{6}$ (about $93.5 \%$ of the 1975 population) to $6.41 \times 10^{6}$ (about $54 \%$ of 2016 population) (Figure 8). As the contribution of renewable emergy remains almost constant, the population has increased 2.73 times from 1975 to 2016, which has shrunk Rwanda's carrying capacity. The renewable carrying capacity is also calculated towards the advanced system. Based on the present Rwandan living standard, the developed carrying capacity is calculated by multiplying the renewable carrying capacity by eight [64], which yields $5.32 \times 10^{07}$ populations in 2016 or fourfold that of the 2016 Rwanda population (Figure 8).

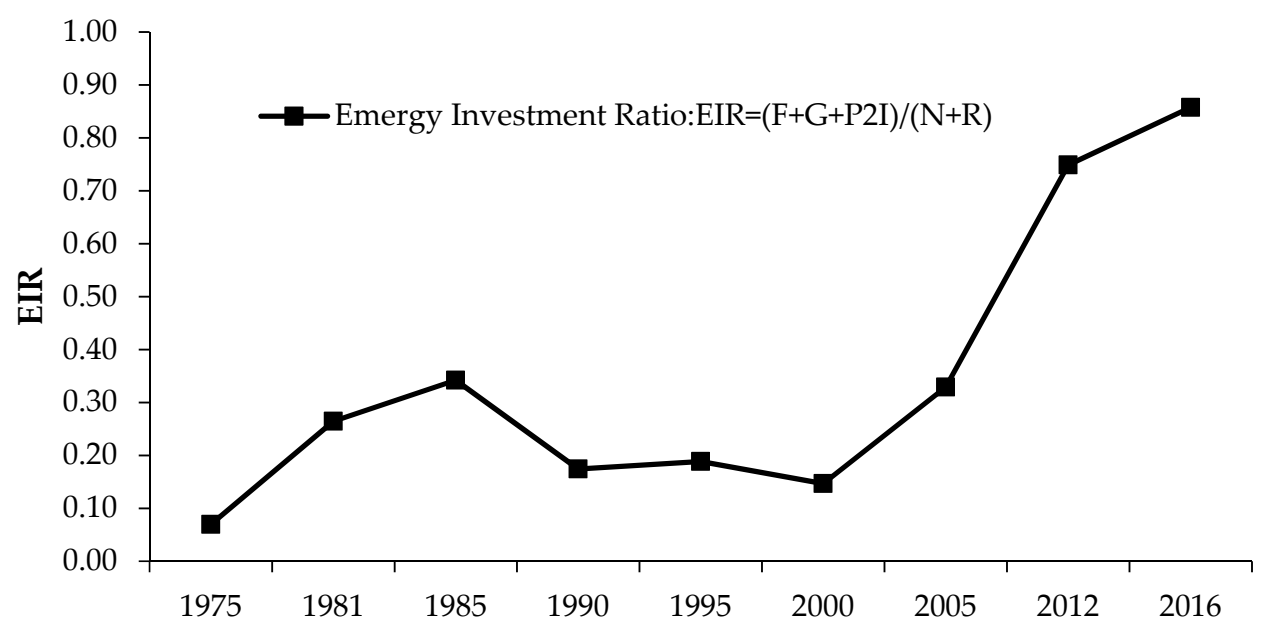

Figure 9. The trend of the emergy investment ratio.

\subsection{Emergy Indicator Analysis by the Economic Level of a Country}

The emergy indicators and indices of 20 countries were analysed to verify if there is a difference based on the country's economic development level. Nine of them were developing countries, and the others were developed countries (Table 1). Based on the Mann-Whitney two-tailed test $(p>0.05)$, the emdollar, the import/export ratio, the ESR, the ELR, and the ratio of electricity to use were significant, with respective $p$-values of $0.001,0.019,0.008,0.005$, and 0.006 . Only EUP and the empower density were not significant, with $p$-values of 0.185 and 0.102 , respectively. 
Table 1. Emergy indicators for Rwanda and other selected countries of the world.

\begin{tabular}{|c|c|c|c|c|c|c|c|c|c|}
\hline Country & $\begin{array}{l}\text { Total Emergy } \\
\text { Use E20sej/Year }\end{array}$ & $\begin{array}{l}\text { Emergy Use } \\
\text { Per Person } \\
\text { E15sej/Person }\end{array}$ & $\begin{array}{c}\text { Emergy/Money } \\
\text { Ratio } \\
\text { E12sej/USD }\end{array}$ & $\begin{array}{c}\text { Empower } \\
\text { Density E11 } \\
\text { sej/m2/Year }\end{array}$ & $\begin{array}{c}\text { Emergy } \\
\text { Import/Export }\end{array}$ & $\begin{array}{c}\text { Emergy } \\
\text { Self-Support Ratio } \\
(\%)\end{array}$ & $\begin{array}{l}\text { Environmental } \\
\text { Loading Ratio }\end{array}$ & $\begin{array}{l}\text { The Ratio of } \\
\text { Electricity } \\
\text { to Use } \%\end{array}$ & $\begin{array}{c}\text { Emergy } \\
\text { Sustainable } \\
\text { Index (ESI) }\end{array}$ \\
\hline Rwanda/2016 * & 631 & 5.3 & 7.54 & 23.97 & 3.38 & 54 & 0.86 & 1.4 & 2.52 \\
\hline Canada/2011 a & 57,200 & 173 & 4.22 & 5.99 & 0.46 & 76 & 2.3 & - & 1.59 \\
\hline Portugal/2009 $\mathrm{b}$ & 14,500 & 136 & 1.18 & 157.00 & 0.97 & 54 & 22.57 & - & 0.10 \\
\hline Italy $/ 2008^{c}$ & 33,700 & 55.2 & 2.15 & 110.00 & 1.60 & - & 15.80 & - & 0.09 \\
\hline Brazil/2008 ${ }^{\mathrm{c}}$ & 40,000 & 21.0 & 2.75 & 4.69 & 0.75 & - & 0.25 & - & 23.82 \\
\hline China/ $2004^{* *}$ & 192,400 & 15.3 & 12.0 & 20.76 & 0.64 & 81 & 9.29 & 8.84 & \\
\hline Australia ** & 8850 & 59.0 & 6.4 & 1.42 & 0.39 & 92 & 0.86 & 6.8 & - \\
\hline Dominica ** & 7 & 13.0 & 14.9 & 8.80 & 0.84 & 69 & 2.67 & $<0.01$ & - \\
\hline Ecuador ** & 964 & 10.7 & 8.7 & 3.40 & 0.20 & 94 & 0.54 & 3.2 & - \\
\hline India ** & 6750 & 1.0 & 6.4 & 2.05 & 1.45 & 88 & 1.02 & 10 & - \\
\hline Japan ** & 15,300 & 12.6 & 2.1 & 41.09 & 4.2 & 31 & 8.34 & 26.1 & - \\
\hline Liberia ** & 465 & 26.0 & 34.5 & 4.10 & 0.15 & 92 & 0.09 & 1.0 & - \\
\hline Netherlands ** & 3702 & 26.0 & 2.2 & 100.00 & 4.30 & 23 & 15.9 & 10.0 & - \\
\hline $\begin{array}{l}\text { Papua N. } \\
\text { Guinea ** }\end{array}$ & 1216 & 35.0 & 48 & 2.63 & 0.09 & 96 & 0.15 & 0.8 & - \\
\hline Poland ** & 964 & 9.6 & 6 & 10.60 & 0.65 & 66 & 19.78 & 18.0 & - \\
\hline Spain ** & 2090 & 6.0 & 1.6 & 3.12 & 2.30 & 24 & 7.20 & 22.0 & - \\
\hline Sweden $* *$ & 4110 & 48.0 & 2.6 & 10.00 & 1.30 & 46 & 7.04 & 23.5 & - \\
\hline Switzerland ${ }^{* *}$ & 733 & 12.0 & 0.7 & 17.70 & 3.20 & 19 & 7.44 & 32.0 & - \\
\hline Thailand ** & 1509 & 3.2 & 3.7 & 2.15 & 0.54 & 70 & 1.04 & 10.8 & - \\
\hline USA ** & 117,800 & 41.9 & 1.19 & 12.53 & 1.27 & 72 & 5.85 & 3.8 & - \\
\hline
\end{tabular}

${ }^{*}$ Current study; ${ }^{* *}$ Extracted from Jiang et al. [47], ${ }^{\mathrm{a}}$ Hossaini and Hewage [18], ${ }^{\mathrm{b}}$ Hossaini and Hewage [19], ${ }^{\mathrm{c}}$ Pereira et al. [54]. 


\section{Conclusions}

This paper accounts for the environmental resources flow of the Rwandan economy from 1975 to 2016 based on the emergy method. The total emergy use (U) increased from $3.63 \times 10^{22}$ sej in 1975 to $6.31 \times 10^{22}$ sej in 2016, and this increase is mainly associated with the increase in imported resources. The proportion of the imported emergy increased from $6.5 \%$ in 1975 to $46.17 \%$ in 2016. Meanwhile, the contribution of renewable resources (R) decreased from 93.48 to $53.76 \%$ as $\mathrm{R}$ was constant throughout 41 years of the study period. Rwanda has become more dependent on foreign goods and services, and less on its indigenous environmental resources. The real human wealth or emergy per person in 2016 declined by about $36 \%$ that of 1975 . The population almost tripled from 1975 , which is the major cause of such a decrease since the total emergy, from 1975 to 2016, increased by $74 \%$. The lowest values of the environmental load ratio (ELR) and emergy investment ratio (EIR) in 1975 implies the low dependence on purchased resources. Despite the decrease in the emergy self-support ratio (ESR) from 0.94 to 0.53 , the indigenous environment contribution is still the major contributor to the total emergy use in Rwanda.

Over a period of 41 years, three major phases were identified in the Rwandan economic development. The first phase (1975-1985), which spans 10 years, is defined by an increase in the imports and a very slow growth of exports, which dropped the import/export ratio from 0.31 in 1975 to 0.13 in 1985. The second phase ranged from 1985 to 2000 when Rwanda experienced political insecurity, and both the inflows and outflows then decreased profoundly in 1994, during the Tutsi genocide. The relatively stable political security during this phase resulted in an increased emergy yield ratio from 3.9 to 7.8 (1985-2000) and a corresponding decreased purchased resources. The ESI increased from 11.46 to 53.26 , as the system was almost dependent on the indigenous resources. The fraction of locally renewable use changed its trend and increased from 74.5 to $87.2 \%$, the total emergy use decreased by $15 \%$, the imports decreased by $57 \%$, and the exports decreased by $12 \%$ in 2000 , compared with those in 1985. Since 2000, the third phase (2000-2016) started with the national economic reform under Vision 2020 to transform Rwanda into a middle-income country by 2020 . The ESI decreased to 2.52 and Rwanda was categorised as a developing economy. The ESI similarity with the developed country was due to the trivial contribution of non-renewable resources to total emergy use in Rwanda, as it is a country that does not have many minerals and other non-renewable resources, as do some developing countries. Thus, its ESI behaves differently from other developing countries for which the major source of a booming economy is from minerals and non-renewable resources exports. Based on ESI analysis, Rwanda is a non-renewable resource-poor country and has a tendency to be judged as a developed country with high non-renewable resources under the preservation policy in which they prefer to import non-renewable resources from outside the system than using its domestic resources.

The present study highly recommends the policy and decision makers of Rwanda to reform its importation by carefully selecting raw materials and non-renewable resources subject to be transformation in Rwanda and then exported after being transformed. This will increase the export, thus minimising the import/export imbalance and trading inequity.

Author Contributions: L.Z. and Ev.R. conceived and designed the research; Ev.R. collected and analysed data; Ev.R., E.F.A., M.P., and Em.R. contributed in discussion; and Ev.R. wrote the paper.

Acknowledgments: This work was supported by the National Science and Technology Major Project of the Ministry of Science and Technology of China (2017YFC0505703), the special fund of State Key Joint Laboratory of Environment Simulation and Pollution Control (No. 17L02ESPC), and WWF Prince Bernhard Scholarships for Nature Conservation 2015.

Conflicts of Interest: The authors declare no conflict of interest. The founding sponsors had no role in the design of the study; in the collection, analyses, or interpretation of data; in the writing of the manuscript; or in the decision to publish the results. 


\section{Appendix A}

Table A1. Emergy evaluation of resource basis for Rwanda (1975-2016)/Solar Emergy sej/year.

\begin{tabular}{|c|c|c|c|c|c|c|c|c|c|c|}
\hline \multirow{2}{*}{ No } & \multirow{2}{*}{ Item } & \multicolumn{4}{|c|}{ Pre-Genocide } & \multicolumn{4}{|c|}{ Post-Genocide } & \multirow[b]{2}{*}{2016} \\
\hline & & 1975 & 1981 & 1985 & 1990 & 1995 & 2000 & 2005 & 2012 & \\
\hline \multicolumn{11}{|c|}{ Renewable sources flow within Rwanda } \\
\hline 1 & Sunlight & $1.31 \times 10^{20}$ & $1.31 \times 10^{20}$ & $1.31 \times 10^{20}$ & $1.31 \times 10^{20}$ & $1.31 \times 10^{20}$ & $1.31 \times 10^{20}$ & $1.31 \times 10^{20}$ & $1.31 \times 10^{20}$ & $1.31 \times 10^{20}$ \\
\hline 2 & Wind, kinetic & $6.92 \times 10^{18}$ & $6.92 \times 10^{18}$ & $6.92 \times 10^{18}$ & $6.92 \times 10^{18}$ & $6.92 \times 10^{18}$ & $6.92 \times 10^{18}$ & $6.92 \times 10^{18}$ & $6.92 \times 10^{18}$ & $6.92 \times 10^{18}$ \\
\hline 3 & Rain, geo potential & $2.92 \times 10^{22}$ & $2.92 \times 10^{22}$ & $2.92 \times 10^{22}$ & $2.92 \times 10^{22}$ & $2.92 \times 10^{22}$ & $2.92 \times 10^{22}$ & $2.92 \times 10^{22}$ & $2.92 \times 10^{22}$ & $2.92 \times 10^{22}$ \\
\hline 4 & Rain, chemical & $4.77 \times 10^{21}$ & $4.77 \times 10^{21}$ & $4.77 \times 10^{21}$ & $4.77 \times 10^{21}$ & $4.77 \times 10^{21}$ & $4.77 \times 10^{21}$ & $4.77 \times 10^{21}$ & $4.77 \times 10^{21}$ & $4.77 \times 10^{21}$ \\
\hline 5 & Earth cycle & $2.85 \times 10^{21}$ & $2.85 \times 10^{21}$ & $2.85 \times 10^{21}$ & $2.85 \times 10^{21}$ & $2.85 \times 10^{21}$ & $2.85 \times 10^{21}$ & $2.85 \times 10^{21}$ & $2.85 \times 10^{21}$ & $2.85 \times 10^{21}$ \\
\hline \multicolumn{11}{|c|}{ Indigenous renewable resources (sej/yr) } \\
\hline 6 & Forestry extraction & $1.71 \times 10^{21}$ & $2.08 \times 10^{21}$ & $2.39 \times 10^{21}$ & $2.82 \times 10^{21}$ & $2.22 \times 10^{21}$ & $3.29 \times 10^{21}$ & $3.69 \times 10^{21}$ & $4.49 \times 10^{21}$ & $4.67 \times 10^{21}$ \\
\hline 7 & Hydro-electricity & $5.65 \times 10^{19}$ & $7.82 \times 10^{19}$ & $9.13 \times 10^{19}$ & $7.81 \times 10^{19}$ & $7.45 \times 10^{19}$ & $2.03 \times 10^{20}$ & $9.14 \times 10^{19}$ & $3.83 \times 10^{20}$ & $6.88 \times 10^{20}$ \\
\hline 8 & Crop production & $1.44 \times 10^{21}$ & $1.89 \times 10^{21}$ & $2.10 \times 10^{21}$ & $1.96 \times 10^{21}$ & $1.29 \times 10^{21}$ & $1.95 \times 10^{21}$ & $3.52 \times 10^{21}$ & $5.52 \times 10^{21}$ & $3.36 \times 10^{21}$ \\
\hline 9 & Livestock & $1.34 \times 10^{21}$ & $1.82 \times 10^{21}$ & $1.92 \times 10^{21}$ & $2.04 \times 10^{21}$ & $1.62 \times 10^{21}$ & $2.46 \times 10^{21}$ & $3.47 \times 10^{21}$ & $4.65 \times 10^{21}$ & $6.73 \times 10^{21}$ \\
\hline \multicolumn{11}{|c|}{ Non-renewable sources flow within Rwanda } \\
\hline 10 & Top soil loss & $3.21 \times 10^{18}$ & $3.21 \times 10^{18}$ & $3.21 \times 10^{18}$ & $3.21 \times 10^{18}$ & $3.21 \times 10^{18}$ & $3.21 \times 10^{18}$ & $3.21 \times 10^{18}$ & $3.21 \times 10^{18}$ & $3.21 \times 10^{18}$ \\
\hline 11 & Cassiterite & $1.88 \times 10^{18}$ & $1.57 \times 10^{18}$ & $5.99 \times 10^{17}$ & $8.59 \times 10^{17}$ & $2.10 \times 10^{17}$ & $3.14 \times 10^{17}$ & $3.30 \times 10^{18}$ & $3.96 \times 10^{18}$ & $3.04 \times 10^{18}$ \\
\hline 12 & Coltan & $6.52 \times 10^{16}$ & $0.00 \mathrm{E}+00$ & $0.00 \mathrm{E}+00$ & $0.00 \mathrm{E}+00$ & $1.12 \times 10^{17}$ & $1.24 \times 10^{18}$ & $1.58 \times 10^{18}$ & $2.37 \times 10^{18}$ & $2.63 \times 10^{18}$ \\
\hline 13 & Wolframite & $7.91 \times 10^{18}$ & $5.20 \times 10^{18}$ & $3.90 \times 10^{18}$ & $1.96 \times 10^{18}$ & $1.90 \times 10^{17}$ & $1.44 \times 10^{18}$ & $1.03 \times 10^{18}$ & $1.75 \times 10^{19}$ & $1.72 \times 10^{18}$ \\
\hline 14 & Other minerals & $4.20 \times 10^{16}$ & 0.00 & $7.45 \times 10^{16}$ & $1.68 \times 10^{17}$ & 0.00 & 0.00 & $8.98 \times 10^{18}$ & $1.17 \times 10^{17}$ & $0.00 \mathrm{E}+00$ \\
\hline 15 & Methane gas & 0.00 & 0.00 & $1.53 \times 10^{18}$ & $1.48 \times 10^{18}$ & $1.43 \times 10^{17}$ & $2.98 \times 10^{17}$ & $1.17 \times 10^{18}$ & $1.53 \times 10^{18}$ & $4.33 \times 10^{19}$ \\
\hline \multicolumn{11}{|c|}{ Imported Fuel } \\
\hline 16 & Fuel: Petroleum Products (j) & $8.45 \times 10^{19}$ & $1.66 \times 10^{20}$ & $2.19 \times 10^{20}$ & $2.25 \times 10^{20}$ & $1.47 \times 10^{20}$ & $2.30 \times 10^{20}$ & $3.08 \times 10^{20}$ & $6.60 \times 10^{20}$ & $8.11 \times 10^{20}$ \\
\hline \multicolumn{11}{|c|}{ Import Goods and Services } \\
\hline 17 & Construction Material & $1.31 \times 10^{20}$ & $2.55 \times 10^{20}$ & $2.36 \times 10^{20}$ & $1.76 \times 10^{20}$ & $9.56 \times 10^{19}$ & $1.50 \times 10^{20}$ & $9.23 \times 10^{20}$ & $1.70 \times 10^{21}$ & $1.77 \times 10^{21}$ \\
\hline 18 & Food products & $6.46 \times 10^{20}$ & $3.83 \times 10^{21}$ & $6.23 \times 10^{21}$ & $1.58 \times 10^{21}$ & $2.96 \times 10^{21}$ & $1.79 \times 10^{21}$ & $2.29 \times 10^{21}$ & $4.42 \times 10^{21}$ & $6.84 \times 10^{21}$ \\
\hline 19 & $\begin{array}{l}\text { Transport, machines and } \\
\text { tools }\end{array}$ & $5.21 \times 10^{20}$ & $1.11 \times 10^{21}$ & $1.30 \times 10^{21}$ & $1.02 \times 10^{21}$ & $1.26 \times 10^{21}$ & $1.53 \times 10^{21}$ & $4.47 \times 10^{21}$ & $1.30 \times 10^{22}$ & $1.29 \times 10^{22}$ \\
\hline 20 & Fertilisers & $2.11 \times 10^{18}$ & $3.21 \times 10^{18}$ & $2.88 \times 10^{19}$ & $6.35 \times 10^{17}$ & $9.49 \times 10^{18}$ & $4.58 \times 10^{19}$ & $2.47 \times 10^{20}$ & $2.47 \times 10^{20}$ & $2.47 \times 10^{20}$ \\
\hline 21 & Miscellaneous & $6.53 \times 10^{20}$ & $1.33 \times 10^{21}$ & $1.10 \times 10^{21}$ & $8.19 \times 10^{20}$ & $7.47 \times 10^{20}$ & $7.99 \times 10^{20}$ & $2.91 \times 10^{21}$ & $5.31 \times 10^{21}$ & $5.15 \times 10^{21}$ \\
\hline 22 & Import services & $3.25 \times 10^{20}$ & $2.28 \times 10^{21}$ & $2.49 \times 10^{21}$ & $2.09 \times 10^{21}$ & $1.19 \times 10^{21}$ & $1.21 \times 10^{21}$ & $2.29 \times 10^{19}$ & $7.69 \times 10^{19}$ & $1.42 \times 10^{21}$ \\
\hline \multicolumn{11}{|c|}{ Export Goods and Services } \\
\hline 23 & Coffee & $7.59 \times 10^{19}$ & $8.26 \times 10^{19}$ & $9.19 \times 10^{19}$ & $9.15 \times 10^{19}$ & $4.28 \times 10^{19}$ & $4.45 \times 10^{19}$ & $5.27 \times 10^{19}$ & $4.83 \times 10^{19}$ & $5.30 \times 10^{19}$ \\
\hline 24 & Tea & $3.11 \times 10^{18}$ & $5.09 \times 10^{18}$ & $7.34 \times 10^{18}$ & $9.40 \times 10^{18}$ & $3.16 \times 10^{18}$ & $1.08 \times 10^{19}$ & $1.34 \times 10^{19}$ & $1.80 \times 10^{19}$ & $1.95 \times 10^{19}$ \\
\hline
\end{tabular}


Table A1. Cont.

\begin{tabular}{|c|c|c|c|c|c|c|c|c|c|c|}
\hline \multirow{2}{*}{ No } & \multirow{2}{*}{ Item } & \multicolumn{4}{|c|}{ Pre-Genocide } & \multicolumn{4}{|c|}{ Post-Genocide } & \multirow[b]{2}{*}{2016} \\
\hline & & 1975 & 1981 & 1985 & 1990 & 1995 & 2000 & 2005 & 2012 & \\
\hline 25 & Minerals & $9.90 \times 10^{18}$ & $6.77 \times 10^{18}$ & $4.57 \times 10^{18}$ & $2.99 \times 10^{18}$ & $5.12 \times 10^{17}$ & $3.00 \times 10^{18}$ & $1.24 \times 10^{19}$ & $2.40 \times 10^{19}$ & $7.38 \times 10^{18}$ \\
\hline 26 & Miscellaneous & $4.17 \mathrm{E}+16$ & $1.22 \times 10^{20}$ & $2.83 \times 10^{20}$ & $1.17 \times 10^{20}$ & $2.04 \times 10^{20}$ & $7.83 \times 10^{19}$ & $4.22 \times 10^{21}$ & $1.14 \times 10^{22}$ & $1.02 \times 10^{21}$ \\
\hline 27 & Export services & $6.35 \times 10^{20}$ & $1.83 \times 10^{21}$ & $1.15 \times 10^{21}$ & $8.39 \times 10^{20}$ & $2.32 \times 10^{20}$ & $1.21 \times 10^{21}$ & $6.05 \times 10^{20}$ & $3.73 \times 10^{21}$ & $7.51 \times 10^{21}$ \\
\hline \multicolumn{11}{|c|}{ Additional information of the Rwandan economy } \\
\hline 23 & Population & $4.36 \times 10^{6}$ & $5.31 \times 10^{6}$ & $6.11 \times 10^{6}$ & $7.21 \times 10^{6}$ & $5.66 \times 10^{6}$ & $8.40 \times 10^{6}$ & $9.43 \times 10^{6}$ & $1.15 \times 10^{7}$ & $1.19 \times 10^{7}$ \\
\hline 24 & Area (square meter) & $2.63 \times 10^{10}$ & $2.63 \times 10^{10}$ & $2.63 \times 10^{10}$ & $2.63 \times 10^{10}$ & $2.63 \times 10^{10}$ & $2.63 \times 10^{10}$ & $2.63 \times 10^{10}$ & $2.63 \times 10^{10}$ & $2.63 \times 10^{10}$ \\
\hline 25 & Exchange rate $\$$ to $\mathrm{Rwf}$ & 92.28 & 102.73 & 94.67 & 78.83 & 246.68 & 458.55 & 546.66 & 607.55 & 780.48 \\
\hline 26 & GNP $(\$)$ & $6.00 \times 10^{8}$ & $1.50 \times 10^{9}$ & $1.80 \times 10^{9}$ & $1.80 \times 10^{9}$ & $1.20 \times 10^{9}$ & $1.70 \times 10^{9}$ & $2.60 \times 10^{9}$ & $7.10 \times 10^{9}$ & $8.38 \times 10^{9}$ \\
\hline
\end{tabular}

Table A2. Indices using emergy for an overview of Rwanda.

\begin{tabular}{|c|c|c|c|c|c|c|c|c|c|c|c|}
\hline \multirow[b]{2}{*}{ No } & \multirow[b]{2}{*}{ Name of Index } & \multirow[b]{2}{*}{ Expression } & \multirow[b]{2}{*}{1975} & \multicolumn{2}{|c|}{ Pre-Genocide } & \multicolumn{6}{|c|}{ Post Genocide } \\
\hline & & & & 1981 & 1985 & 1990 & 1995 & 2000 & 2005 & 2012 & 2016 \\
\hline 1 & Renewable emergy flow_R & $\mathrm{R}$ & $3.39 \times 10^{22}$ & $3.39 \times 10^{22}$ & $3.39 \times 10^{22}$ & $3.39 \times 10^{22}$ & $3.39 \times 10^{22}$ & $3.39 \times 10^{22}$ & $3.39 \times 10^{22}$ & $3.39 \times 10^{22}$ & $3.39 \times 10^{22}$ \\
\hline 2 & $\begin{array}{l}\text { Indigenous Non-renewable } \\
\text { Resources }\end{array}$ & $\mathrm{N}=\mathrm{N} 0+\mathrm{N} 1$ & $3.21 \times 10^{18}$ & $3.21 \times 10^{18}$ & $4.73 \times 10^{18}$ & $4.69 \times 10^{18}$ & $3.35 \times 10^{18}$ & $3.50 \times 10^{18}$ & $4.38 \times 10^{18}$ & $4.73 \times 10^{18}$ & $4.65 \times 10^{19}$ \\
\hline 3 & Import emergy & $\mathrm{G}+\mathrm{F}+\mathrm{P} 2 \mathrm{I}$ & $2.36 \times 10^{21}$ & $8.97 \times 10^{21}$ & $1.16 \times 10^{22}$ & $5.91 \times 10^{21}$ & $6.40 \times 10^{21}$ & $4.98 \times 10^{21}$ & $1.12 \times 10^{22}$ & $2.54 \times 10^{22}$ & $2.91 \times 10^{22}$ \\
\hline 4 & Total emergy use_U & $\mathrm{N} 0+\mathrm{N} 1+\mathrm{R}+\mathrm{G}+\mathrm{F}+\mathrm{P} 2 \mathrm{I}$ & $3.63 \times 10^{22}$ & $4.29 \times 10^{22}$ & $4.55 \times 10^{22}$ & $3.98 \times 10^{22}$ & $4.03 \times 10^{22}$ & $3.89 \times 10^{22}$ & $4.51 \times 10^{22}$ & $5.93 \times 10^{22}$ & $6.31 \times 10^{22}$ \\
\hline 5 & Total export emergy & $\mathrm{E}=\mathrm{B}+\mathrm{N} 2+\mathrm{P} 1 \mathrm{E}$ & $7.23 \times 10^{20}$ & $2.05 \times 10^{21}$ & $1.53 \times 10^{21}$ & $1.06 \times 10^{21}$ & $4.83 \times 10^{20}$ & $1.35 \times 10^{21}$ & $4.90 \times 10^{21}$ & $1.52 \times 10^{22}$ & $8.61 \times 10^{21}$ \\
\hline 6 & Total emergy inflows (sej/yr) & $\mathrm{R}+\mathrm{N}+\mathrm{F}+\mathrm{G}+\mathrm{P} 2 \mathrm{I}$ & $3.63 \times 10^{22}$ & $4.29 \times 10^{22}$ & $4.55 \times 10^{22}$ & $3.98 \times 10^{22}$ & $4.03 \times 10^{22}$ & $3.89 \times 10^{22}$ & $6.26 \times 10^{21}$ & $5.93 \times 10^{22}$ & $6.31 \times 10^{22}$ \\
\hline 7 & Exports minus imports (sej/yr) & $(\mathrm{B}+\mathrm{N} 2+\mathrm{P} 1 \mathrm{E})-(\mathrm{F}+\mathrm{G}+\mathrm{P} 2 \mathrm{I})$ & $-1.64 \times 10^{21}$ & $-6.92 \times 10^{21}$ & $-1.01 \times 10^{22}$ & $-4.85 \times 10^{21}$ & $-5.92 \times 10^{21}$ & $-3.63 \times 10^{21}$ & $-6.26 \times 10^{21}$ & $-1.02 \times 10^{22}$ & $-2.05 \times 10^{22}$ \\
\hline 8 & Ratio of exports to imports & $(\mathrm{B}+\mathrm{N} 2+\mathrm{P} 1 \mathrm{E}) /(\mathrm{F}+\mathrm{G}+\mathrm{P} 2 \mathrm{I})$ & 0.31 & 0.23 & 0.13 & 0.18 & 0.08 & 0.27 & 0.44 & 0.60 & 0.30 \\
\hline 9 & Indigenous sources & $\mathrm{R}+\mathrm{N}$ & $3.39 \times 10^{22}$ & $3.39 \times 10^{22}$ & $3.39 \times 10^{22}$ & $3.39 \times 10^{22}$ & $3.39 \times 10^{22}$ & $3.39 \times 10^{22}$ & $3.39 \times 10^{22}$ & $3.39 \times 10^{22}$ & $3.40 \times 10^{22}$ \\
\hline 10 & Emergy to money ratio (sej/\$) & U/GNP & $6.05 \times 10^{13}$ & $2.86 \times 10^{13}$ & $2.53 \times 10^{13}$ & $2.21 \times 10^{13}$ & $3.36 \times 10^{13}$ & $2.29 \times 10^{13}$ & $1.73 \times 10^{13}$ & $8.36 \times 10^{12}$ & $7.54 \times 10^{12}$ \\
\hline 11 & Environmental loading ratio (ELR) & $(\mathrm{N}+\mathrm{F}+\mathrm{G}+\mathrm{P} 2 \mathrm{I}) / \mathrm{R}$ & 0.07 & 0.26 & 0.34 & 0.17 & 0.19 & 0.15 & 0.33 & 0.75 & 0.86 \\
\hline 12 & Emergy investment ratio (EIR) & $(\mathrm{F}+\mathrm{G}+\mathrm{P} 2 \mathrm{I}) /(\mathrm{N}+\mathrm{R})$ & 0.07 & 0.26 & 0.34 & 0.17 & 0.19 & 0.15 & 0.33 & 0.75 & $8.58 \mathrm{E}-01$ \\
\hline 13 & Emergy yield ratio (EYR) & $\mathrm{U} /(\mathrm{F}+\mathrm{G}+\mathrm{P} 2 \mathrm{I})$ & 15.36 & 4.78 & 3.92 & 6.74 & 6.30 & 7.82 & 4.04 & 2.34 & $2.17 \mathrm{E}+00$ \\
\hline 14 & Emergy sustainability index (ESI) & EYR/ELR & 220.26 & 18.08 & 11.46 & 38.70 & 33.42 & 53.26 & 12.27 & 3.12 & 2.52 \\
\hline 15 & Emergy self-support ratio (ESR) & $(\mathrm{N}+\mathrm{R}) / \mathrm{U}$ & $93.49 \%$ & $79.09 \%$ & $74.51 \%$ & $85.17 \%$ & $84.14 \%$ & $87.21 \%$ & $75.24 \%$ & $57.19 \%$ & $53.83 \%$ \\
\hline 16 & Fraction use, locally renewable & $\mathrm{R} / \mathrm{U}$ & $93.48 \%$ & $79.08 \%$ & $74.50 \%$ & $85.16 \%$ & $84.13 \%$ & $87.20 \%$ & $75.23 \%$ & $57.18 \%$ & $53.76 \%$ \\
\hline 17 & $\begin{array}{l}\text { Fraction of emergy use purchased } \\
\text { (imports) }\end{array}$ & $(\mathrm{F}+\mathrm{G}+\mathrm{P} 2 \mathrm{I}) / \mathrm{U}$ & $6.51 \%$ & $20.91 \%$ & $25.49 \%$ & $14.83 \%$ & $15.86 \%$ & $12.79 \%$ & $24.76 \%$ & $42.81 \%$ & $46.17 \%$ \\
\hline 18 & Fraction import service & $\mathrm{P} 2 \mathrm{I} / \mathrm{U}$ & $0.90 \%$ & $5.32 \%$ & $5.47 \%$ & $5.24 \%$ & $2.94 \%$ & $1.11 \%$ & $0.05 \%$ & $0.13 \%$ & $2.26 \%$ \\
\hline
\end{tabular}


Table A2. Cont.

\begin{tabular}{|c|c|c|c|c|c|c|c|c|c|c|c|}
\hline \multirow[b]{2}{*}{ No } & \multirow[b]{2}{*}{ Name of Index } & \multirow[b]{2}{*}{ Expression } & \multirow[b]{2}{*}{1975} & \multicolumn{2}{|c|}{ Pre-Genocide } & \multicolumn{6}{|c|}{ Post Genocide } \\
\hline & & & & 1981 & 1985 & 1990 & 1995 & 2000 & 2005 & 2012 & 2016 \\
\hline 19 & Fraction of use that is free & $(\mathrm{R}+\mathrm{No}) / \mathrm{U}$ & $93.49 \%$ & $79.09 \%$ & $74.51 \%$ & $85.17 \%$ & $84.14 \%$ & $87.21 \%$ & $75.24 \%$ & $57.18 \%$ & $5.38 \times 10^{-1}$ \\
\hline 20 & Ratio of concentrated to rural & $(\mathrm{F}+\mathrm{G}+\mathrm{P} 2 \mathrm{I}+\mathrm{N} 2) /(\mathrm{R}+\mathrm{N} 0+\mathrm{N} 1)$ & 0.07 & 0.26 & 0.34 & 0.17 & 0.19 & 0.15 & 0.33 & 0.75 & 0.86 \\
\hline 21 & Use per unit area, empower density & $\mathrm{U} /\left(\right.$ area- $\left.\mathrm{m}^{2}\right)$ & $1.38 \times 10^{12}$ & $1.63 \times 10^{12}$ & $1.73 \times 10^{12}$ & $1.51 \times 10^{12}$ & $1.53 \times 10^{12}$ & $1.48 \times 10^{12}$ & $1.71 \times 10^{12}$ & $2.25 \times 10^{12}$ & $2.40 \times 10^{12}$ \\
\hline 22 & Emergy use per person (EUP) & U/population & $8.33 \times 10^{15}$ & $8.08 \times 10^{15}$ & $7.45 \times 10^{15}$ & $5.52 \times 10^{15}$ & $7.12 \times 10^{15}$ & $4.64 \times 10^{15}$ & $4.78 \times 10^{15}$ & $5.18 \times 10^{15}$ & $5.30 \times 10^{15}$ \\
\hline 23 & $\begin{array}{l}\text { Renewable carrying capacity at } \\
\text { present living standard }\end{array}$ & $(\mathrm{R} / \mathrm{U}) *($ population$)$ & $4.07 \times 10^{6}$ & $4.20 \times 10^{6}$ & $4.55 \times 10^{6}$ & $6.14 \times 10^{6}$ & $4.76 \times 10^{6}$ & $7.32 \times 10^{6}$ & $7.09 \times 10^{6}$ & $6.55 \times 10^{6}$ & $6.41 \times 10^{6}$ \\
\hline 24 & $\begin{array}{l}\text { Developed carrying capacity at same } \\
\text { living standard }\end{array}$ & $8(\mathrm{R} / \mathrm{U}) *($ population$)$ & $3.26 \times 10^{7}$ & $3.36 \times 10^{7}$ & $3.64 \times 10^{7}$ & $4.92 \times 10^{7}$ & $3.81 \times 10^{7}$ & $5.86 \times 10^{7}$ & $5.68 \times 10^{7}$ & $5.24 \times 10^{7}$ & $5.13 \times 10^{7}$ \\
\hline 25 & Ratio of electricity to use & $(\mathrm{el}) / \mathrm{U}$ & $0.20 \%$ & $0.29 \%$ & $0.26 \%$ & $0.44 \%$ & $0.19 \%$ & $0.52 \%$ & $0.40 \%$ & $0.80 \%$ & $1.41 \%$ \\
\hline 26 & Fuel use per person & fuel/Population & $1.94 \times 10^{13}$ & $3.13 \times 10^{13}$ & $3.58 \times 10^{13}$ & $3.12 \times 10^{13}$ & $2.60 \times 10^{13}$ & $2.74 \times 10^{13}$ & $3.04 \times 10^{13}$ & $5.53 \times 10^{13}$ & $6.80 \times 10^{13}$ \\
\hline 27 & Ratio Rwanda to world emdollar & P1/P2 & 3.24 & 1.92 & 1.21 & 1.15 & 2.92 & 10.08 & 8.46 & 5.04 & 4.54 \\
\hline
\end{tabular}

Table A3. Summary of flows in the Rwandan economy (1975-2012).

\begin{tabular}{|c|c|c|c|c|c|c|c|c|c|c|c|}
\hline & \multirow{2}{*}{ Item } & \multirow{2}{*}{ Unit } & \multicolumn{4}{|c|}{ Pre-Genocide } & \multicolumn{5}{|c|}{ Post-Genocide } \\
\hline & & & 1975 & 1981 & 1985 & 1990 & 1995 & 2000 & 2005 & 2012 & 2016 \\
\hline $\mathrm{R}$ & Renewable sources & $\mathrm{sej} / \mathrm{yr}$ & $3.39 \times 10^{22}$ & $3.39 \times 10^{22}$ & $3.39 \times 10^{22}$ & $3.39 \times 10^{22}$ & $3.39 \times 10^{22}$ & $3.39 \times 10^{22}$ & $3.39 \times 10^{22}$ & $3.39 \times 10^{22}$ & $3.39 \times 10^{22}$ \\
\hline $\mathrm{N}$ & Non-renewable Resources & $\mathrm{sej} / \mathrm{yr}$ & $3.21 \times 10^{18}$ & $3.21 \times 10^{18}$ & $4.73 \times 10^{18}$ & $4.69 \times 10^{18}$ & $3.35 \times 10^{18}$ & $3.50 \times 10^{18}$ & $4.38 \times 10^{18}$ & $4.73 \times 10^{18}$ & $4.65 \times 10^{19}$ \\
\hline NO & Local Disposal resources & $\mathrm{sej} / \mathrm{yr}$ & $3.21 \times 10^{18}$ & $3.21 \times 10^{18}$ & $3.21 \times 10^{18}$ & $3.21 \times 10^{18}$ & $3.21 \times 10^{18}$ & $3.21 \times 10^{18}$ & $3.21 \times 10^{18}$ & $3.21 \times 10^{18}$ & $3.21 \times 10^{18}$ \\
\hline N1 & Local Concentrated use & $\mathrm{sej} / \mathrm{yr}$ & 0.00 & 0.00 & $1.53 \times 10^{18}$ & $1.48 \times 10^{18}$ & $1.43 \times 10^{17}$ & $2.98 \times 10^{17}$ & $1.17 \times 10^{18}$ & $1.53 \times 10^{18}$ & $4.33 \times 10^{19}$ \\
\hline N2 & Export of unprocessed material & $\mathrm{sej} / \mathrm{yr}$ & $9.90 \times 10^{18}$ & $6.77 \times 10^{18}$ & $4.57 \times 10^{18}$ & $2.99 \times 10^{18}$ & $5.12 \times 10^{17}$ & $3.00 \times 10^{18}$ & $1.53 \times 10^{19}$ & $2.40 \times 10^{19}$ & $7.38 \times 10^{18}$ \\
\hline $\mathrm{F}$ & 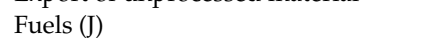 & $\mathrm{sej} / \mathrm{yr}$ & $8.45 \times 10^{19}$ & $1.66 \times 10^{20}$ & $2.19 \times 10^{20}$ & $2.25 \times 10^{20}$ & $1.47 \times 10^{20}$ & $2.30 \times 10^{20}$ & $3.08 \times 10^{20}$ & $6.60 \times 10^{20}$ & $8.11 \times 10^{20}$ \\
\hline E & Dollars paid for imports & $\$$ & $8.38 \times 10^{7}$ & $1.92 \times 10^{8}$ & $2.22 \times 10^{8}$ & $2.92 \times 10^{8}$ & $2.31 \times 10^{8}$ & $2.41 \times 10^{8}$ & $2.99 \times 10^{8}$ & $1.85 \times 10^{9}$ & $2.02 \times 10^{9}$ \\
\hline E3 & Dollars paid for import services & $\$$ & $1.74 \times 10^{7}$ & $1.53 \times 10^{8}$ & $1.19 \times 10^{8}$ & $1.09 \times 10^{8}$ & $1.03 \times 10^{8}$ & $2.98 \times 10^{8}$ & $3.35 \times 10^{8}$ & $4.63 \times 10^{7}$ & $2.25 \times 10^{9}$ \\
\hline G & Import Goods & $\mathrm{sej} / \mathrm{yr}$ & $1.95 \times 10^{21}$ & $6.52 \times 10^{21}$ & $8.90 \times 10^{21}$ & $3.60 \times 10^{21}$ & $5.07 \times 10^{21}$ & $4.32 \times 10^{21}$ & $1.08 \times 10^{22}$ & $2.47 \times 10^{22}$ & $2.69 \times 10^{22}$ \\
\hline P2E & Import Services & $\mathrm{sej} / \mathrm{yr}$ & $3.25 \times 10^{20}$ & $2.28 \times 10^{21}$ & $2.49 \times 10^{21}$ & $2.09 \times 10^{21}$ & $1.19 \times 10^{21}$ & $4.43 \times 10^{20}$ & $2.29 \times 10^{19}$ & $7.69 \times 10^{19}$ & $1.42 \times 10^{21}$ \\
\hline I & Dollars received for exports & $\$$ & $4.20 \times 10^{7}$ & $7.42 \times 10^{7}$ & $1.40 \times 10^{8}$ & $1.05 \times 10^{8}$ & $5.97 \times 10^{7}$ & $5.66 \times 10^{7}$ & $8.44 \times 10^{7}$ & $4.83 \times 10^{8}$ & $5.99 \times 10^{8}$ \\
\hline I3 & Dollars paid for export services & $\$$ & $1.05 \times 10^{7}$ & $6.41 \times 10^{7}$ & $4.53 \times 10^{7}$ & $3.79 \times 10^{7}$ & $6.91 \times 10^{6}$ & $5.30 \times 10^{7}$ & $3.49 \times 10^{7}$ & $4.47 \times 10^{8}$ & $9.97 \times 10^{8}$ \\
\hline $\mathrm{B}+\mathrm{N} 2$ & Export Goods & $\mathrm{sej} / \mathrm{yr}$ & $8.89 \times 10^{19}$ & $2.17 \times 10^{20}$ & $3.87 \times 10^{20}$ & $2.21 \times 10^{20}$ & $2.50 \times 10^{20}$ & $1.37 \times 10^{20}$ & $4.30 \times 10^{21}$ & $1.15 \times 10^{22}$ & $1.10 \times 10^{21}$ \\
\hline P1I & Export Services & $\mathrm{sej} / \mathrm{yr}$ & $6.35 \times 10^{20}$ & $1.83 \times 10^{21}$ & $1.15 \times 10^{21}$ & $8.39 \times 10^{20}$ & $2.32 \times 10^{20}$ & $1.21 \times 10^{21}$ & $6.05 \times 10^{20}$ & $3.73 \times 10^{21}$ & $7.51 \times 10^{21}$ \\
\hline B & Export products transformed within & $\mathrm{sej} / \mathrm{yr}$ & $7.90 \times 10^{19}$ & $8.77 \times 10^{19}$ & $9.92 \times 10^{19}$ & $1.01 \times 10^{20}$ & $4.60 \times 10^{19}$ & $5.52 \times 10^{19}$ & $1.26 \times 10^{20}$ & $1.77 \times 10^{20}$ & $8.10 \times 10^{19}$ \\
\hline P2 & World emdollar & sej/\$ & $1.87 \times 10^{13}$ & $1.49 \times 10^{13}$ & $2.09 \times 10^{13}$ & $1.92 \times 10^{13}$ & $1.15 \times 10^{13}$ & $2.27 \times 10^{12}$ & $2.05 \times 10^{12}$ & $1.66 \times 10^{12}$ & $1.66 \times 10^{12}$ \\
\hline \multirow[t]{2}{*}{ P1 } & Rwanda emdollar & $\mathrm{sej} / \$$ & $6.05 \times 10^{13}$ & $2.86 \times 10^{13}$ & $2.53 \times 10^{13}$ & $2.21 \times 10^{13}$ & $3.36 \times 10^{13}$ & $2.29 \times 10^{13}$ & $1.73 \times 10^{13}$ & $8.24 \times 10^{12}$ & $7.54 \times 10^{12}$ \\
\hline & GNP (\$) & $\$$ & $6.00 \times 10^{8}$ & $1.50 \times 10^{9}$ & $1.80 \times 10^{9}$ & $1.80 \times 10^{9}$ & $1.20 \times 10^{9}$ & $1.70 \times 10^{9}$ & $2.60 \times 10^{9}$ & $7.10 \times 10^{9}$ & $8.38 \times 10^{9}$ \\
\hline
\end{tabular}




\section{References}

1. Wilson, M.A.; Howarth, R.B. Discourse-based valuation of ecosystem services: Establishing fair outcomes through group deliberation. Ecol. Econ. 2002, 41, 431-443. [CrossRef]

2. Shaw, R.P. Rapid population growth and environmental degradation: Ultimate versus proximate factors. Environ. Conserv. 1989, 16, 199-208. [CrossRef] [PubMed]

3. Alam, S. Globalization, Poverty and Environmental Degradation: Sustainable Development in Pakistan. Sustain. Dev. 2010, 3, 103-114. [CrossRef]

4. Shafik, N. Economic Development and Environmental Quality: An Econometric Analysis. Oxf. Econ. Pap. 1994, 46, 757-773. [CrossRef]

5. International Monetary Fund (IMF). Regional Economic Outlook: Sub-Saharan Africa Restarting the Growth Engine; International Monetary Fund (IMF): Washington, DC, USA, 2017.

6. Kimball, S.; Lulow, M.; Sorenson, Q.; Balazs, K.; Fang, Yi.; Davis, S.J.; O'Connell, M.; Huxman, T.E. Cost-effective ecological restoration. Restor. Ecol. 2015, 23, 800-810. [CrossRef]

7. Harte, J. Human population as a dynamic factor in environmental degradation. Popul. Environ. 2007, 28, 223-236. [CrossRef]

8. Ray, S. Impact of Population Growth on Environmental Degradation: Case of India. J. Econ. Sustain. Dev. 2011, 2, 72-78.

9. Atiqul, S.H.; Vanwing, T. Perception, Environmental Degradation and Family Size Preference: A Context of Developing Countries. J. Sustain. Dev. 2010, 3, 102-108. [CrossRef]

10. Economic Commission for Africa (ECA). The Demography Profile of African Countries; Economic Commission for Africa (ECA): Addis Ababa, Ethiopia, 2016.

11. Lei, K.; Hu, D.; Zhou, S.; Guo, Z. Monitoring the sustainability and equity of socioeconomic development: A comparison of emergy indices using Macao, Italy and Sweden as examples. Acta Ecol. Sin. 2012, 32, 165-173. [CrossRef]

12. Giannetti, B.F.; Ogura, Y.; Bonilla, S.H.; Almeida, C.M.V.B. Emergy assessment of a coffee farm in Brazilian Cerrado considering in a broad form the environmental services, negative externalities and fair price. Agric. Syst. 2011, 104, 679-688. [CrossRef]

13. Liu, G.; Yang, Z.; Chen, B.; Ulgiati, S. Emergy-based dynamic mechanisms of urban development, resource consumption and environmental impacts. Ecol. Model. 2014, 271, 90-102. [CrossRef]

14. Tilley, D.R.; Swank, W.T. EMERGY-based environmental systems assessment of a multi-purpose temperate mixed-forest watershed of the southern Appalachian Mountains, USA. J. Environ. Manag. 2003, 69, 213-227. [CrossRef]

15. Yang, Z.F.; Jiang, M.M.; Chen, B.; Zhou, J.B.; Chen, G.Q.; Li, S.C. Solar emergy evaluation for Chinese economy. Energy Policy 2010, 38, 875-886. [CrossRef]

16. Sawyerr, A. African Universities and the Challenge of Research Capacity Development. J. High. Educ. Afr./Rev. l'enseignement supérieur en Afrique 2004, 2, 211-240.

17. Kayizzi-Mugerwa, S. Reforming Africa's Institutions Ownership, Incentives, and Capabilities; United Nations University: New York, NY, USA, 2003.

18. Hossaini, N.; Hewage, K. Emergy accounting for regional studies: Case study of Canada and its provinces. J. Environ. Manag. 2013, 118, 177-185. [CrossRef] [PubMed]

19. Oliveira, C.; Martins, C.; Gonçalves, J.; Veiga, F. Solar Emergy Evaluation of the Portuguese Economy. In Proceedings of the 7th Biennial Conference on Emergy and Environmental Accounting-Theories, Applications and Methodologies, Center for Environmental Policy-University of Florida, Gainesville, FL, USA, 12-14 January 2012; pp. 437-451.

20. Zhang, L.X.; Ulgiati, S.; Yang, Z.F.; Chen, B. Emergy evaluation and economic analysis of three wetland fish farming systems in Nansi Lake area, China. J. Environ. Manag. 2011, 92, 683-694. [CrossRef] [PubMed]

21. Lehmensiek, M. Evaluation of Tourism in the Okavango Delta in Botswana Using Environmental Accounting; University of Florida: Gainesville, FL, USA, 2004; p. 86.

22. Sarkis, J.; Ulgiati, S. China-USA Trade: Indicators for Equitable and Environmentally Balanced Resource Exchange. Ecol. Econ. 2017, 132, 245-254.

23. Ulgiati, S.; Odum, H.T.; Bastianoni, S. Emergy use, environmental loading and sustainability an emergy analysis of Italy. Ecol. Model. 1994, 73, 215-268. [CrossRef] 
24. Coscieme, L.; Pulselli, F.M.; Marchettini, N.; Sutton, P.C.; Anderson, S.; Sweeney, S. Emergy and ecosystem services: A national biogeographical assessment. Ecosyst. Serv. 2014, 7, 152-159. [CrossRef]

25. Ulgiati, S. A Comprehensive Energy and Economic Assessment of Biofuels: When 'Green' Is Not Enough. CRC Crit. Rev. Plant Sci. 2001, 20,71-106. [CrossRef]

26. Rutebuka, E.; Zhang, L.; Pang, M. Simulating the Dynamics of E-waste Production from Mobile Phone: Model Development and Case Study of Rwanda. J. Environ. Account. Manag. 2015, 3, 309-322. [CrossRef]

27. The World Bank. Rwanda Economic Update: Seeds for Higher Growth; The World Bank: Kigali, Rwanda; Washington, DC, USA, 2011.

28. National Institute of Statistic of Rwanda (NISR). Statistical Yearbook 2014; National Institute of Statistic of Rwanda (NISR): Kigali, Rwanda, 2014.

29. United Nations Development Programme (UNDP). Turning Vision 2020 into Reality from Recovery to Sustainable Human Development; UNDP: Kigali, Rwanda, 2007.

30. Kaberuka, D. Rwanda Vision 2020; MINECOFIN: Kigali, Rwanda, 2000.

31. Diao, X.; Bahiigwa, G.; Pradesha, A. The Role of Agriculture in the Fast-Growing Rwandan Economy: Assessing Growth Alternatives; The International Food Policy Reaserch Institute (IFPRS): Washington, DC, USA, 2014.

32. Malunda, D. African Centre for Economic Transformation (ACET) Rwanda: Case Study on Economic Transformation; Institute of Policy Analysis and Research-Rwanda (IPAR): Kigali, Rwanda, 2012.

33. Rutayisire, M.J. Economic Liberalization, Monetary Policy and Money Demand in Rwanda: 1980-2005; African Economic Research Consortium: Nairobi, Kenya, 2010; Volume 193.

34. Ggombe, K.; Newfarmer, R. Rwanda: From Devastation to Services-First Transformation; No. 2017/84; United Nations University-World Institute for Development Economic Research (UNU-WIDER): Helsinki, Finland, 2017.

35. Odum, H.T. Environmental Accounting. Emergy and Environmental Decision Making; John Wiley and Sons: New York, NY, USA, 1996.

36. Brown, M.T.; Bardi, E.; Campbell, D.E.; Comar, V.; Haung, S.-L.; Tilley, D. Theory and Applications of the Emergy Methodology Emergy. Emergy Synth. 2005, 3, 362-371.

37. Brown, M.; Herendeen, R. Embodied energy analysis and EMERGY analysis: A comparative view. Ecol. Econ. 1996, 19, 219-235. [CrossRef]

38. Brown, M.T.; Ulgiati, S. Energy quality, emergy, and transformity: H.T. Odum's contributions to quantifying and understanding systems. Ecol. Model. 2004, 178, 201-213. [CrossRef]

39. Odum, H.T.; Brown, M.T.; Brandt-Williams, S. Handbook of Emergy Evaluation A: Introduction and Global Budget; University of Florida: Gainesville, FL, USA, 2000.

40. Brown, M.T.; Ulgiati, S. Assessing the global environmental sources driving the geobiosphere: A revised emergy baseline. Ecol. Model. 2016, 339, 126-132. [CrossRef]

41. Brown, M.T.; Ulgiati, S. Emergy assessment of global renewable sources. Ecol. Model. 2016, 339, $148-156$. [CrossRef]

42. Chen, G.Q.; Jiang, M.M.; Chen, B.; Yang, Z.F.; Lin, C. Emergy analysis of Chinese agriculture. Agric. Ecosyst. Environ. 2006, 115, 161-173. [CrossRef]

43. Campbell, D.E.; Ohrt, A. Environmental Accounting Using Emergy: Evaluation of Minnesota; US Environmental Protection Agency (USEPA): Washington, DC, USA, 2009.

44. Lefroy, E.; Rydberg, T. Emergy evaluation of three cropping systems in southwestern Australia. Ecol. Model. 2003, 161, 195-211. [CrossRef]

45. Brown, M.T.; Bardi, E. A Compendium of Data for Emergy Computation: Handbook of Emergy Evaluation; University of Florida: Gainesville, FL, USA, 2001.

46. Murdoch, A. 10 Facts about Hunger in Rwanda. World Food Programme (WFP), 2015. Available online: https:/ / www.wfp.org/stories/10-facts-about-hunger-rwanda (accessed on 4 May 2018).

47. Jiang, M.M.; Zhou, J.B.; Chen, B.; Chen, G.Q. Emergy-based ecological account for the Chinese economy in 2004. Commun. Nonlinear Sci. Numer. Simul. 2008, 13, 2337-2356. [CrossRef]

48. Lei, K.; Wang, Z. Emergy synthesis of tourism-based urban ecosystem. J. Environ. Manag. 2008, 88, 831-844. [CrossRef] [PubMed]

49. Agostinho, F.; Ortega, E. Integrated food, energy and environmental services production as an alternative for small rural properties in Brazil. Energy 2012, 37, 103-114. [CrossRef]

50. National Bank of Rwanda (BNR). Foreign Private Investment in Rwanda 2015; National Bank of Rwanda (BNR): Kigali, Rwanda, 2015. 
51. Brown, M.T.; Ulgiati, S. Emergy-based indices and ratios to evaluate sustainability: Monitoring economies and technology toward environmentally sound innovation. Ecol. Eng. 1997, 9, 51-69. [CrossRef]

52. Campbell, D.E.; Brandt-Williams, S.L.; Meisch, M.E.A. Environmental Accounting Using Emergy: Evaluation of the State of West Virginia; U.S. Environmental Protection Agency: Washington, DC, USA, 2009.

53. United Nations (UN). Investment Policy Review Rwanda; United Nations (UN): New York, NY, USA, 2006.

54. Pereira, L.; Zucaro, A.; Ortega, E.; Ulgiati, S. Wealth, trade and environment in brazil and Italy. An emergy-based comparison of carrying capacity, economic performance and wellbeing. In Proceedings of the 7th Biennial International Workshop Advances in Energy Studies, Barcelona, Spain, 19-21 October 2010.

55. Kampeng, L.; Shaoqi, Z.; Wang, Z. Ecological Emergy Accounting for a Limited System: General Principles and a Case Study of Macao; Science Press: Beijing, China; Springer: Berlin/Heidelberg, Germany, 2014.

56. Hagström, P.; Nilsson, P.O. Emergy Evaluation of the Swedish Economy since the 1950s. In Proceedings of the Third Biennial Emergy Conference, Gainesville, FL, USA, 29-31 January 2004; pp. 1-18.

57. Brown, M.T.; Ulgiati, S. Emergy evaluations and environmental loading of electricity production systems. J. Clean. Prod. 2002, 10, 321-334. [CrossRef]

58. Meng, W.; Hao, C.; Li, H.; Ju, M. Emergy analysis for sustainability evaluation of the Baiyangdian wetland ecosystem in China. Front. Environ. Sci. Eng. 2010, 4, 203-212. [CrossRef]

59. Lou, B.; Ulgiati, S. Identifying the environmental support and constraints to the Chinese economic growth-An application of the Emergy Accounting method. Energy Policy 2013, 55, 217-233. [CrossRef]

60. Campbell, D.E. Emergy analysis of human carrying capacity and regional sustainability: An example using the State of Maine. Environ. Monit. Assess. 1998, 51, 531-569. [CrossRef]

61. Brown, M.T.; Ulgiati, S. Emergy measures of carrying capacity to evaluate economic investments. Popul. Environ. 2001, 22, 471-501. [CrossRef]

62. Nakajima, E.S.; Ortega, E. Carrying Capacity Using Emergy Evaluation and Ecological Footprint. In Proceedings of the 8th Biennial Emergy, Gainesville, FL, USA, 15-18 January 2014; pp. 261-274.

63. Cavalett, O.; Ortega, E. Creation of a Global Emergy Database for Standardized National Emergy Synthesis. Emergy Synth. 2007, 4, 483-497.

64. Brown, M.T.; McClanahan, T.R. Emergy analysis perspectives of Thailand and Mekong River dam proposals. Ecol. Model. 1996, 91, 105-130. [CrossRef] 